
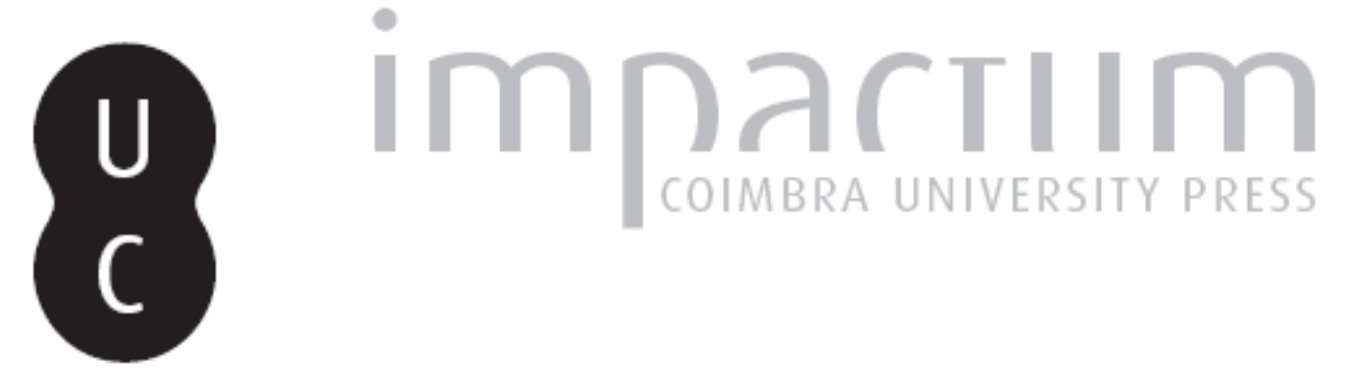

\title{
A evolução da cultura castreja
}

\section{Autor(es): $\quad$ Alarcão, Jorge de}

Publicado por: Imprensa da Universidade de Coimbra

URL persistente:

URI:http://hdl.handle.net/10316.2/45508

DOI:

DOI:https://dx.doi.org/10.14195/1647-8657_31_3

Accessed : $\quad$ 26-Apr-2023 14:38:21

A navegação consulta e descarregamento dos títulos inseridos nas Bibliotecas Digitais UC Digitalis, UC Pombalina e UC Impactum, pressupõem a aceitação plena e sem reservas dos Termos e Condições de Uso destas Bibliotecas Digitais, disponíveis em https://digitalis.uc.pt/pt-pt/termos.

Conforme exposto nos referidos Termos e Condições de Uso, o descarregamento de títulos de acesso restrito requer uma licença válida de autorização devendo o utilizador aceder ao(s) documento(s) a partir de um endereço de IP da instituição detentora da supramencionada licença.

Ao utilizador é apenas permitido o descarregamento para uso pessoal, pelo que o emprego do(s) título(s) descarregado(s) para outro fim, designadamente comercial, carece de autorização do respetivo autor ou editor da obra.

Na medida em que todas as obras da UC Digitalis se encontram protegidas pelo Código do Direito de Autor e Direitos Conexos e demais legislação aplicável, toda a cópia, parcial ou total, deste documento, nos casos em que é legalmente admitida, deverá conter ou fazer-se acompanhar por este aviso.

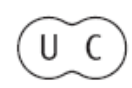


FACULDADE DE LETRAS

INSTITUTO DE ARQUEOLOGIA

\section{CONIMBRIGA}

VOLUME XXXI

,

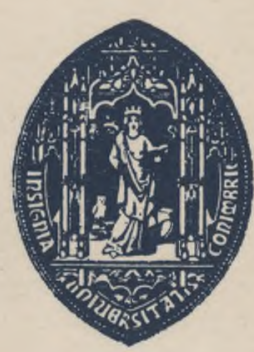

UNIVERSIDADE DE COIMBRA

1992 
JoRGE DE ALARCÃo

Professor da Faculdade de Letras de Coimbra

\section{A EVOLUÇÃO DA CULTURA CASTREJA}

«Conimbriga» XXXI (1992), p. 39-71

RESUMO : O autor distingue três fases fundamentais na evolução da cultura castrej a.

Uma, de integração económica e sociopolítica, correspondente aos séculos X a VIII a. C, com redes de trocas e chefes organizadores da produção e circulação. Outra, entre os inícios do séc. VII e os fins do II a. C., de reversão a uma estrutura igualitária e acéfala, com supressão ou amortecimento das trocas e desaparecimento dos chefes. A partir dos finais do séc. II a. C., outra novamente de integração política, levada mais longe que a da primeira fase, agora com evidentes lugares centrais. $\mathrm{O}$ autor pretende ainda explicar por razões económicas a integração da primeira fase e por motivos políticos ou militares aquela que se observa a partir de finais do séc. II a. C.

RÉSUMÉ: L'auteur considère trois grandes périodes dans l'évolution de la culture des "castros" ou oppida du nord du Portugal. Du Xe au VIII e siècle avant J.C., des réseaux de circulation du bronze auraient conduit à la formation d'unités politiques, sous l'égide de chefs dont la fonction aurait été 1'organization de la production et de la circulation du bronze. Du VII siècle jusqu'à la fin du IIe la région aurait connu un procès de regréssion sociale, revenant à une forme moins évoluée. À la fin du II siècle avant J.C. aurait commencé une nouvelle phase d'intégration économique et sociale, qui aurait conduit à la formation de places centrales comme Briteiros ou Sanfins. L'auteur essaie d'expliquer l'intégration sociale de la première phase par des méchanismes économiques et celle de la dernière période par des raisons politiques et militaires. 
(Página deixada propositadamente em branco) 


\section{A EVOLUÇÃO DA CULTURA CASTREJA}

\section{Introdução}

O território actualmente português foi culturalmente diverso no primeiro milénio a.C.. Numa primeira abordagem, poderemos dividi-lo em duas áreas: a galaico-lusitana ou castreja e a céltico-túrdula.

Callaeci e Lusitani parecem designações aplicadas pelos Romanos a conjuntos de povos cujos nomes particulares se podem reconstituir através das fontes literárias e epigráficas. Os Callaeci seriam inicialmente uma etnia situada imediatamente a norte do Douro, na província que hoje toma o nome de Douro Litoral (Tranoy, 1981: 65). O nome étnico parece ter sido transformado pelos Romanos num colectivo para designar múltiplos populi do Noroeste. Quanto ao nome de Lusitani, podemos duvidar se alguma vez designou uma particular etnia. Os Romanos usaram-no como um colectivo para denominar populações do Portugal central e da Extremadura espanhola.

A área que designamos de galaico-lusitana ou castreja compreende, em primeiro lugar, todo o Norte do país acima do Douro. Junto ao litoral, viria até ao Vouga; pelo interior, ultrapassava o Tejo e englobava o Nordeste alentejano. Já Untermann, nos seus mapas linguísticos, mostrou as afinidades do Nordeste alentejano com as Beiras (1965:19) (vide aqui Fig. 1); e José d'Encarnaçâo (1984) demonstrou de forma indiscutível as afinidades onomásticas das duas regiões, afinidades aliás também observáveis no plano dos cultos indígenas. Por outro lado, há, nas fontes clássicas, referências expressas aos Lusitanos a sul do Tejo $\left({ }^{1}\right)$.

(9 Por exemplo, em ApIANO, Ib. 57 e Orosius, 4, 21,10. 
Nesta vasta zona galaico-lusitana será necessário fazer subdivisões, por enquanto incertas. A região a norte do Douro não era homogénea: basta pensar nos castros transmontanos, com torreões e por vezes pedras fincadas que não surgem no Minho e na distribuição dos berrões ou verracos que em Portugal também se circunscrevem à parte oriental de Trás-os-Montes. Apesar dos muitos trabalhos efectuados desdes os finais do séc. XIX sobre a cultura castreja, não é todavia ainda possível traçar um quadro das dissemelhanças regionais e definir subáreas de cultura material (2).

Designamos por área céltico-túrdula a zona a sul do Tejo (com excepção do Nordeste alentejano) e a fachada atlântica do Tejo até ao Vouga. Não havia aqui apenas Celtici e Turduli, cuja presença se deduz das fontes clássicas. Havia ainda, pelo menos, Conii. A um quadro de múltipla exclusão étnica, com cada povo em sua área, devemos talvez preferir um outro de considerável convivência, com aglomerados urbanos pluri-étnicos, embora cada estrato pudesse manter a sua língua e as manifestações simbólicas da sua identidade, o que daria aos povoados uma feição variegada.

Com o estabelecimento dos Turduli Veteres imediatamente a sul do Douro (SILVA, 1983), talvez no séc. III a. C., a área céltico-túrdula foi alargada.

É a evolução da área galaico-lusitana ou castreja que aqui nos interessa.

A cultura castreja foi recentemente objecto de duas importantes monografias: a de Armando Coelho Ferreira da Silva, A cultura castreja no Noroeste de Portugal (1986) e a de Manuela Martins, O povoamento proto-histórico e a romanização da bacia do curso médio do Cávado (1990), esta última precedida por três relatórios de escavações que lhe serviram de fundamento (MARTINS, 1988a, 1988b, 1989).

Ambos os autores propõem quadros cronológico-culturais. O primeiro divide a cultura castreja em três períodos e subdivide cada um deles em duas fases:

IA: de 900 a 700 a.C.

IB: de 700 a 500 a.C.

IIA: de 500 a 200 a.C.

(2) A tese de doutoramento que Francisco Sande Lemos prepara é um valioso contributo para a definição da especificidade da parte oriental de Trás-os-Montes. 
IIB: de 200 a.C. 140 a.C.

IIIA: de c. 140 aos fins do séc. I a.C.

IIIB: de fins do séc. I a.C. à época dos Flávios

Manuela Martins, por seu lado, propõe quatro fases (1990: 112)

I: séc. X/IX a VII/VI a.C.

II: séc. VII/VI a finais do II a.C.

III: finais do séc. II a.C. a meados do I d.C.

IV: meados do séc. I d.C. ao séc. III

O quadro, aparentemente mais preciso, de Armando Coelho F. da Silva valoriza certas datas, como 500 ou 200 a.C., que nos parecem discutíveis por razões que exporemos no decurso deste artigo. A cultura material acusa consideráveis permanências que não justificam uma cronologia tão fina. Não é possível, por exemplo, e no estado actual dos nossos conhecimentos, distinguir entre cerâmicas da fase HA e da fase IIB. Formas, técnicas e decorações parecem persistir sem alterações do séc. VI aos fins do II a.C.. Porquê estabelecer uma nova fase em 200 a.C.? Porque se verificam a partir desta data algumas importações de cerâmica campaniense (SILVA, 1986:42)? Mas que impacte tiveram essas importações?

Não é nosso objectivo, porém, centrar este artigo na discussão dos quadros cronológico-culturais. Pretendemos antes abordar fenómenos sócio-económicos e sociopolíticos e distinguir três fases fundamentais da evolução: uma de integração económica e sociopolítica, correspondente aos séculos X a VIII a.C., com redes de trocas e chefes organizadores da produção e circulação; outra, entre os inícios do séc. VII e os finais do II a.C., de reversão a uma estrutura igualitária e acéfala, com supressão ou amortecimento das trocas e desaparecimento dos chefes; e, a partir dos finais do séc. II a.C., outra novamente de integração económica e política, levada mais longe que a da primeira fase, agora com evidentes lugares centrais. Pretendemos ainda explicar por razões económicas a integração da primeira fase e por motivos políticos ou militares aquela que se observa a partir de finais do séc. II a.C. 
Do século X ao VII A.C.

No séc. $\mathrm{X}$ a.C. surgem, na área galaico-lusitana, os primeiros castros. As datações de radiocarbono demonstrativas desta cronologia são, por enquanto, e para o território actualmente português, escassas: $1020 \pm 35$ a.C. e $960 \pm 35$ a.C. para o Castro de S. Romão (Seia) (GUERRA et alii, 1989: 194 e 196); $980 \pm 100$ a.C. e $970 \pm 120$ a.C. para o Coto da Pena (Caminha)(SILVA, 1986: 34); $940 \pm 45$ a.C., $890 \pm 80$ a.C. e 870 \pm 40 a.C. para a citânia de S. Julião (Vila Verde) (MARTINS, 1990: 113; veja-se todavia também MARTINS, 1988: 126). São todavia suficientes para admitirmos que o fenómeno de acastelamento ( ${ }^{3}$ ) se iniciou no séc. $\mathrm{X}$ a.C.. Foi esse fenómeno explosivo ou gradual?

O número de castros conhecidos na área galaico-lusitana é elevado. Armando Coelho F. da Silva (1986) registou 922, mas não incluiu no seu inventário a Beira Transmontana, a Beira Baixa nem o Alto Alentejo.

As escavações são insuficientes para nos decidirmos entre um fenómeno explosivo e um crescimento gradual. A explicação migracionista de Lopez-Cuevillas pode classificar-se como explosivista.

Lopez-Cuevillas (1989: 37 e 332; primeira edição em 1953) atribuiu a emergência dos castros à invasão indo-europeia dos Sefes; e, uma vez que estes se encontram já referidos na Ora Marítima de Avieno, poema composto sobre um original da segunda metade do séc. VI a.C., datou da primeira metade deste século a imigração e o fenómeno de acastelamento. A presença, nos castros, de elementos hallstáticos e a raridade das influências de La Tène (período que os proto-historiadores iniciam em 475 a.C.) foram argumentos suplementares com que defendeu a datação. Mesmo que se tenha verificado, no séc. VI a.C., uma invasão de Sefes, não pode mais defender-se a doutrina de Lopez-Cuevillas, dada a grande antiguidade dos primeiros castros.

A visão de Manuela Martins parece gradualista. Admitindo que os primeiros castros surgiram no séc. X a.C., propõe como períodos de acastelamento também os séculos VII-VI ou VI-V a.C. (MARTINS, 1990: 137 e 202). Não nos parecem firmes as bases desta proposta. Porquê estes séculos e não outros? Inclinamo-nos, porém, igualmente para um

$\left(^{3}\right) \quad$ Os Romanos designavam por castellum o tipo de povoamento a que hoje se dá o nome de castro. Daquela palavra latina derivamos acastelamento, para designar o fenómeno histórico de instalação dos povoados nos altos. 
acastelamento gradual, explicável por um crescimento populacional regular, todavia impossível de medir.

Temos, porém, de explicar porque é que, no séc. $\mathrm{X}$ a.C., algumas populações começaram a instalar-se no alto dos montes, em lugares de acesso difícil e de fácil defesa, com campos de visibilidade amplos. A explicação do acastelamento constitui um dos temas mais incómodos da Proto-história peninsular, evitado por alguns investigadores, claramente formulado por outros sem uma hipótese explicativa convincente.

A explicação que mais rapidamente ocorre é a da competição. As populações procuravam os altos e fortificavam-se porque se guerreavam.

Poderia aqui aduzir-se o texto de Estrabão, III 3, 5:

"Cerca de trinta povos ocupam a região que se situa entre o Tejo e os Ártabros. Se bem que a região fosse muito favorecida, no que respeita a frutos, animais e quantidade de ouro, prata e outros metais similares, outrora a maioria desses povos, negligenciando os meios de subsistência que a terra produzia, entregavam-se à pilhagem e viviam em guerra, quer uns com os outros, quer com os vizinhos do outro lado do Tejo, até que foram travados pelos Romanos que os tornaram submissos e reduziram a aldeias a maior parte das suas cidades, ou associaram a outras colónias que as tornaram melhores. Foram as populações das montanhas que começaram com a referida anomia, como é natural: por habitarem um solo miserável e possuírem parcos recursos, cobiçavam os bens dos outros povos. E estes, que os tentavam repelir, deixaram de cuidar dos seus próprios assuntos, a ponto de também eles se dedicarem à guerra, em vez de trabalharem a terra. Em resultado disso, a região, sem cuidados, deixou de produzir bens naturais e encheu-se de salteadores". ( $\left.{ }^{4}\right)$

Corresponderá esta imagem à realidade, ou trata-se de um topos literário?

$\left({ }^{4}\right)$ Tradução do Doutor J. Ribeiro Ferreira, a quem agradecemos. 
O discurso de Galba aos Lusitanos, em 150 a.C., refere-se à escassez de terras:

"A pobreza do solo e a penúria - disse ele - forçam-vos a isso (isto é, ao roubo e à guerra). Mas eu, meus amigos, dar-vos-ei boas terras e fixar-vos-ei numa região fértil”. (Apiano, Ib., 59).

A ser real esta imagem de competição e guerra, verificar-se-ia já nos inícios do primeiro milénio ou será um facto só do séc. II a.C., época à qual provavelmente se reportam as fontes de Estrabão e seguramente o discurso de Galba?

$\mathrm{Na}$ bacia do curso médio do Cávado, Manuela Martins identificou seis castros do Bronze Final: S. Julião, Barbudo, Roriz, Faria, Monte da Saia e S. João de Rei (1990: 119) (vide aqui fig. 2). Consideradas as distâncias relativas destes povoados, cada um deles poderia dispor, à vontade, de um território de uma hora, isto é, de 1850 a 2680 hectares $\left(^{5}\right)$. Admitindo uma economia essencialmente pastoril e uma razão de 3 cabeças de gado ovicaprino por hectare $\left(^{6}\right)$, os territórios desses castros poderiam sustentar 5550 a 8040 ovelhas ou cabras. Ora o número de animais necessário por indivíduo e por ano, num sistema alimentar baseado no consumo de ovicaprinos, parece ser de $60\left({ }^{7}\right)$. Assim, os territórios poderiam sustentar, sem problemas, de 92 a 134 habitantes.

Infelizmente, não temos dados sobre a área dos castros. Manuela Martins apenas determinou a superfície intramuros de S. Julião, que calculou em 600 metros quadrados. Adoptando a ratio de Renfrew para os povoados do Bronze do Egeu (300 habitantes por hectare, ratio que parece a muitos autores exagerada) S. Julião teria 18 habitantes. A mesma

$\left(^{5}\right)$ São estas as áreas correspondentes aos territórios de uma hora dos castros: Barbudo, 1850 hectares; S. Julião, 1870; Roriz, 2100; S. João de Rei, 2250; Monte da Saia, 2570; Faria, 2680 hectares.

$\left(^{6}\right)$ BATICLE, 1974:58 considera que os pastos naturais mediterrânicos podem sustentar, no máximo, três ovicaprinos por hectare. GopHNA et alii, 1986-87: 77 afirma que, na Palestina, um hectare pode sustentar três ovelhas ou cabras. CoELHO, 1982: 17 apresenta, para a Serra da Estrela, a mesma capacidade de sustentação.

$\left(^{7}\right)$ HalsteAd, 1981: 314, aliás seguido por GopHNA et alii, 1986-87: 77, considera que uma população vivendo essencialmente à base de ovicaprinos consome 20 animais por indivíduo e por ano. A dimensão do rebanho que pode, sem se extinguir, proporcionar o abate anual de 20 cabeças é de 60 animais (HALSTEAD, 1981:314). 
autora admite a possibilidade de o povoado comportar oito a dez cabanas circulares. A escavação de uma delas revelou um diâmetro de 5 metros (MARTINS, 1988:135). A área de cada cabana seria assim de cerca de 19,5 metros quadrados, e a área coberta total do povoado, 195 metros quadrados. Se adoptamos a ratio de Hill ( um habitante por cada 4,5 metros quadrados de área coberta) (HASSAN, 1982: 233), teríamos, para S. Julião, 43 habitantes. Este é um número todavia máximo, que supõe a área do povoado apinhada de cabanas, sem pátios ou logradouros.

Qualquer que tenha sido a população de S. Julião, ela foi sempre inferior à capacidade de sustentação do território, pelo que não podemos supor os seus habitantes envolvidos em guerra com vizinhos pela posse de terras essenciais à sustentação.

Evidentemente, S. Julião é apenas um caso. Se a generalização, a partir dele, é imprudente, a existência, no Bronze Final, de uma competição pela terra é todavia duvidosa.

Acresce que a competição deveria traduzir-se, no registo arqueológico, por um número significativo de armas, que parecem, porém, raras no Bronze Final. Por outro lado, a competição deveria ter conduzido a concentrações maiores de população, porque quanto mais as gentes se agregam mais eficientes se tornam a defesa e o ataque. Mas aqui revertemos ao ponto anterior: à parte $\mathrm{S}$. Julião, não dispomos de dados sobre a dimensão média dos povoados do séc. X ou IX a.C.. Aparentemente, os castros foram sempre reduzidos e só nos fins do séc. II ou nos inícios do I a.C. se desenvolveram, no Entre Douro e Minho, alguns povoados maiores, com funções de lugares centrais, como Sanfins ou Briteiros. Segundo Armando Coelho F. da Silva, os povoados da sua fase I não excederiam 2 hectares (SILVA, 1986: 61). O estudo que Sande Lemos tem em curso relativamente à parte oriental de Trás-os-Montes, revela castros com territórios reduzidos: os de 30 minutos excluem-se, mas os de 60 minutos sobrepõem-se. Ora, explorando apenas um território de 30 minutos, um castro não poderia alojar grande população.

Se a competição pela terra parece duvidosa, poderia ela ter-se efectivado noutro campo?

O fenómeno do acastelamento coincide historicamente com a intensificação da produção e circulação do bronze. Produção e circulação implicam uma rede, um circuito.

A fig. 3 propõe um modelo de circulação. Os povoados envolvidos no circuito não representam a totalidade dos povoados existentes. A maioria ficaria à margem dos circuitos e o bronze não teria transformado, 
na generalidade, os meios técnicos de produção da subsistência e dos artefactos. A produção e a circulação do bronze envolveriam apenas um reduzido número de povoados, que classificamos em produtores, transmissores e receptores. Os povoados transmissores, entre os primeiros e os segundos, poderiam ser muito mais numerosos, dependendo da lonjura dos percursos.

Não imaginamos os povoados envolvidos no circuito como lugares centrais, captadores de corveias e de bens alimentares dos povoados menores envolventes. Imaginamos estes auto-suficientes, necessariamente envolvidos numa rede de trocas matrimoniais mas não numa troca de bens (para além daqueles que necessariamente circulariam como dotes de casamento ou preços das noivas) e marginalizados pelos produtores e transportadores do bronze.

No seio dos povoados envolvidos no circuito poderia ter-se estabelecido alguma divisão social do trabalho, da qual emergiria uma classe de metalurgistas, eventualmente uma de comerciantes, e talvez uma de oleiros. Com efeito, nos castros do Bronze Final é visível uma distinção entre cerâmicas grosseiras, que representam provavelmente uma produção doméstica, e cerâmicas finas. Estas últimas são possivelmente um produto de oleiros já especializados (MARTINS, 1990: 127).

A fig. 4 representa um outro modelo possível de relacionamento dos povoados, agora integrados em sistemas piramidais, com castros principais e castros dependentes. O bronze e a cerâmica fina circulariam dos primeiros para os segundos e estes forneceriam àqueles produtos alimentares e eventualmente corveias.

Os dados arqueológicos são, por enquanto, demasiadamente escassos para podermos optar por um ou outro dos modelos. O caso de S. Julião e do Barbudo poderia aduzir-se em favor do primeiro modelo: em S. Julião, no período correspondente aos séculos X/IX-VII/VI a.C., surgiram alguns objectos de bronze, designadamente dois punhais (MARTINS, 1990: 134), enquanto que no Barbudo, povoado contemporâneo e contíguo escavado pela mesma investigadora, não se encontraram, no mesmo período, artefactos metálicos.

A ausência de uma hierarquia piramidal de povoamento favoreceria, porém, uma competição selvagem. Como evitar o ataque dos transportadores de bronze pela população dos castros menores? Só através de escoltas armadas. Neste caso, as armas deveriam encontrar-se com mais abundância; ora, como dissemos, elas parecem raras no registo arqueológico. 
Ambos os modelos pressupõem a existência de chefes, cuja função social seria a de produzir e fazer circular o bronze. Os modelos divergem quanto à generalização do uso do bronze: no primeiro caso temos uma coordenação sequencial de chefes que não distribuiriam os benefícios da liga metálica ao comum da população e, no segundo, uma estrutura piramidal que generalizaria o uso do bronze. Só o progresso das escavações poderá revelar até que ponto o bronze foi adoptado também pelas pequenas comunidades.

Achar-se-á, no registo arqueológico, alguma prova da existência de chefes na área galaico-lusitana ou castreja, no Bronze Final?

Tomemos o caso da Beira Alta. O castro da Senhora da Guia (Baiões), aparentemente destruído cerca de 700 a.C., é preeminente. A produção de artefactos de bronze está aí documentada por um molde. Vários braceletes de bronze, um de ouro e dois torques do mesmo metal são itens sociotécnicos que podemos tomar como testemunho da presença de um chefe. Mais importante ainda que o bracelete e os torques de ouro é o punhal de lâmina de ferro e cabo de bronze que nas ruínas do castro se recolheu. Por volta de 700 a.C., o ferro começava a ser utilizado na franja mediterrânica da Península Ibérica, donde certamente procede esta arma então raríssima e por isso mesmo carregada de prestígio. Algumas taças de bronze poderão ter sido utilizadas em banquetes que, na Europa hallstàtica, eram também uma forma de os chefes demonstrarem e fortalecerem o seu prestígio (BOULOUMIÉ, 1988). Finalmente, uma furcula e alguns carros votivos revelam a função religiosa do chefe (Sobre este espólio, SILVA et alii, 1984). Noutros lugares da Beira Alta recolheram-se outras joias de ouro: um torques em Serrazes (S. Pedro do Sul), outro em Vale da Malhada (Sever do Vouga) e 16 braceletes em Baralhas (Vale de Cambra). A estes achados registados por Armando Coelho F. da Silva (1986:36) deve talvez acrescentar-se o tesouro de dez braceletes de ouro achado cerca de 1929 em Mouchana, em frente à estação do caminho de ferro de Moçâmedes, no vale do Vouga ( ${ }^{8}$ ).

Armando Coelho F. da Silva (1986: 36) tomou a destruição e abandono do castro da Senhora da Guia e o enterramento daquelas joias

$\left.{ }^{8}\right) \quad$ A única referência que conhecemos a este tesouro é a de CoELHO, 1941 : 429, nota 2. O autor data-o da Idade do Bronze e afirma que 5 braceletes eram lisos e roliços e outros 5 largos e canelados. Atribui-lhes o peso global de 350 gramas, o que parece reduzido. José Coelho não observou pessoalmente o tesouro.

Conimbriga, 31 (1992), 39-71 
como indício de uma invasão e daí deduziu uma imigração que generalizou a todo o Noroeste, encerrando em 700 a.C. o seu período IA da cultura castreja.

Mas ter-se-á mesmo verificado, na Beira Alta, por volta de 700 a.C., uma invasão? Convém ensaiar outras explicações. O enterramento das joias pode ter-se verificado em face de uma ameaça próxima; mas 'é igualmente admissível um enterramento ritual $\left({ }^{9}\right)$. Seja como for, estas joias poderão talvez tomar-se como itens sociotécnicos demonstrativos de chefes. Teríamos assim na Beira Alta, entre 900 e 700 a.C., chefados envolvidos na produção e circulação do bronze, eventualmente também do ouro que poderia ser explorado nas minas da região de Castelo de Paiva e na Queiriga (Vila Nova de Paiva). Se o peso das joias é significativo, poderíamos ter chefes suzeranos na Senhora da Guia e Baralhas e vassalos em Serrazes, Vale de Malhada e Mouchana. As joias da Senhora da Guia pesam, no seu conjunto, 1559 gramas. Os dois braceletes sobreviventes do conjunto de dezasseis de Baralhas pesam 202 e 182 gramas; admitindo que os restantes oscilavam entre os mesmos pesos, teríamos 3072 gramas. O torques de Serrazes pesa 574,4 e o bracelete de Vale de Malhada, 94,8 gramas (sobre os pesos vid. SILVA, 1986: 246 a 255).

Ao Bronze Final devem atribuir-se as esteias funerárias de tipo estremenho que podemos tomar também como testemunho da existência de chefes. Estas esteias são frequentes na Extremadura espanhola, donde o seu nome de estremenhas.

Foram bem estudadas por M. Varela Gomes e J. Pinho Monteiro (1977), que distinguiram quatro tipos, seriados cronologicamente entre os séculos XI e VIII a.C. em função do número e da variedade dos motivos representados. Nas mais antigas vêem-se um escudo, uma lança e uma espada. Posteriormente, segundo aqueles autores, surgem representações de espelhos, pentes, fíbulas, carros e capacetes (tipo B). Mais tarde ainda, a figura humana acrescenta-se aos elementos anteriores (tipo C). Finalmente, a figura do guerreiro amplifica-se, rodeada de armas e outros artefactos, e as esteias representam também uma cena (tipo D).

Parece-nos discutível a seriação em função do número e tipo de objectos representados. Poderíamos propor uma diversidade em função

(9) Veja-se o caso dinamarquês estudado por LEVY, 1979 e 1982. 
do status, correspondendo as esteias com maior número de objectos a chefes de status mais elevado.

$\mathrm{Na}$ altura do artigo de M. Varela Gomes e J. Pinho Monteiro conheciam-se apenas duas destas esteias na Beira Baixa: as de Meimão e S. Martinho. Posteriormente, F. Curado publicou outras duas, achadas no concelho do Sabugal: Baraçal e Fóios (CURADO, 1984 e 1986). Propôs para a primeira uma cronologia alta (fins do séc. XII ou inícios do XI a.C.) e relacionou-a com uma provável invasão indo-europeia. Parece-nos discutível esta ideia de uma invasão, todavia não de todo impossível. Mais do que discutir a cronologia das esteias ou a sua relação com uma invasão, interessa-nos aqui sugerir a existência de chefes também na Beira Trasmontana e na Beira Baixa, num momento correspondente talvez aos séculos IX e VIII a.C., época à qual Maria Cruz Fernandez Castro (1988: 273) atribui as estelas. Tais chefes,como os da Beira Alta, estariam envolvidos na produção e circulação do bronze, encaminhado, através da Extremadura espanhola e do Nordeste alentejano, para o Sudoeste peninsular, onde então florescia Tartesso, no seu período antigo ou pré-colonial.

A julgar pelos achados de ourivesaria, o vale do Ave é outra zona do vasto território galaico-lusitano ou castrejo onde, entre 900 e 700 a.C., se pode ter constituído outro sistema sócio-económico integrado, com chefes dominando a produção e circulação do bronze. Com efeito, Armando Coelho F. da Silva atribui a este período os braceletes de Cantonha (Guimarães), Quinta da Bouça (Vila Nova de Famalicão) e Vila do Conde.

Finalmente, os braceletes de Alto da Pedisqueira (Chaves) e Telões (Vila Pouca de Aguiar) sugerem uma quarta rede de chef ados no vale do Tâmega (sobre todas estas peças de ourivesaria vide SILVA, 1986).

Se a tipologia e o peso dos braceletes são significativos, teríamos em Cantonha um suzerano (peso do bracelete, 230,9 gramas; achado aliás com outras joias, infelizmente desaparecidas) e na Quinta da Bouça (180,2 gramas) e em Vila do Conde (62,5 gramas) dois vassalos. Por seu lado, no Alto da Pedisqueira (121,2 gramas) teríamos o suzerano de um vassalo em Telões (60 gramas). Os braceletes que, por hipótese, atribuímos aos suzeranos são não só mais pesados como tecnicamente mais elaborados. 
Do século VII aos finais do II A.C.

No séc. VII a.C. parece verificar-se o colapso da metalurgia do bronze na vasta área galaico-lusitana: os achados atribuíveis a esta época são raros. Semelhante colapso poderá ter arrastado consigo o desmantelamento das redes de circulação do bronze e conduzido a uma involução da complexidade social, detectável numa quebra significativa das joias e no desaparecimento das formas de cerâmica fina que haviam sido correntes nos séculos anteriores. O peso total das joias do período de $900-$ -700 a.C. é de 6195 gramas $\left({ }^{10}\right)$ e o do período de 700-500, apenas de 1058 (cálculos baseados em SILVA, 1986).

A cerâmica fina não desaparece totalmente do registo arqueológico. Em Conimbriga, por exemplo, sobrevive até aos fins do séc. I a.C. ou aos inícios do I d.C., então extremamente diversificada nas formas. Conimbriga, porém, situa-se numa faixa atlântica cuja história é diferente da do território galaico-lusitano. Neste, o desaparecimento da cerâmica fina parece ser um facto do séc. VII a.C.

"O registo arqueológico — diz Manuela Martins (1990: 189) assinala, a partir do séc. VII a.C., um paulatino empobrecimento da cultura material correlativo de uma escassez de bens reveladores de intercâmbios entre regiões e de uma diminuição da produção metalúrgica." Buscando as razões desse empobrecimento, a autora julga encontrá-las na instalação dos Fenícios no Sudeste peninsular. As exigências fenícias do cobre "terão dificultado naturalmente o acesso das populações setentrionais ao cobre do Sudeste" (1990: 189).

Duvidamos, em primeiro lugar, do interesse comercial dos Fenícios pelo cobre. Parece-nos que os colonizadores pretendiam sobretudo os metais nobres, designadamente a prata; e se buscavam outro menos nobre, seria o estanho, puro ou eventualmente já aliado ao cobre em artefactos de bronze.

A introdução do ferro na faixa mediterrânica peninsular e no Sudoeste (GAMITO, 1991), reduzindo provavelmente a necessidade do bronze, poderá constituir uma explicação alternativa para a queda da produção desta liga no Noroeste. O problema, todavia, afigura-se-nos

$\left({ }^{10}\right)$ O peso das joias do período IA dado por Armando Coelho F. da Silva, 1986, é de 3297, 7 gramas. Acrescentamos o peso do tesouro de Mouchana (350 gramas) e o peso provável das 14 peças desaparecidas de Baralhas (14 x 182 gramas $=2548$ gramas). Obtemos assim, para o período IA, o peso total de 6195, 7 gramas. 
complexo. A produção de ferro ter-se-á intensificado, no séc. VII a.C., de modo a reduzir o consumo do bronze na faixa mediterrânica? Mesmo admitindo uma produção importante de ferro e uma redução percentual do consumo do bronze, o progresso social da faixa mediterrânica não terá contribuído para manter, em termos absolutos, a exigência anterior?

O longo período de involução que propomos, entre o séc. VII e os finais do II a.C., desenvolvendo aliás uma ideia de Manuela Martins, é subdividido por Armando Coelho F. da Silva em três fases: IB (700-500 a.C.), IIA (500-200 a.C.) e IIB (200- c. 140 a.C.). Já acima duvidámos do significado de 200 a.C., data a partir da qual Armando Coelho F. da Silva julga terem-se realizado algumas importações de cerâmica campaniense. Será a data de 500 a.C. mais significativa?

É nesta data que o autor situa a imigração de Celtici e Turduli, referida nestes termos por Estrabão (III, 3, 5):

"Os últimos de todos (os povos) são os Artabros e habitam junto do cabo que se chamaNério eéo extremo da costa ocidental e norte. Também os Célticos habitam próximo desse cabo e são aparentados com os que vivem junto do Anas. Diz-se que eles e os Túrdulos, durante uma expedição a estes sítios, se revoltaram após passarem o rio Lima; que depois da revolta e da perda do seu chefe, se dispersaram e se fixaram nesses lugares; e que, por essa razão, o rio recebeu o nome de Letes".

A veracidade do relato estraboniano é indiscutível. Mela (III, 1, 8) situa na fachada atlântica os Turduli Veteres, que Plínio (IV, 35,113), por seu lado, localiza imediatamente a sul do Douro. As tesserae hospitales descobertas por Armando Coelho F. da Silva (1983) na base do castro de Nossa Senhora da Saúde ou Monte Murado vieram confirmar essa localização. Se os Turduli desceram até ao sul do Douro, os Celtici remontaram à Galiza, onde Plínio localiza os Celtici Neri e os Celtici Praestamarci (N.H. IV, 111).

Do relato de Estrabão não pode, porém, inferir-se a data da imigração. Armando Coelho F. da Silva propõe 500 a.C. baseando-se em alguns fragmentos de cerâmica de tradição púnica encontrados no Noroeste (1986: 37 e 135). Como reconhece, esses fragmentos não são datáveis com rigor, inscrevendo-se no período que decorre entre os séculos V e III a.C.. Ora uma cronologia mais viável para a imigração parece ser a segunda metade do séc. III a.C., época em que poderá ter-se exercido certa 
pressão dos Cartagineses no Sul de Portugal, donde procedem os Célticos e Túrdulos. Contra, poderá aduzir-se a ausência, no Noroeste, dos motivos estampilhados que parecem frequentes no Alentejo, a partir do séc. V a.C. (ARNAUd e Gamito, 1974-1977; Gamito, 1988:120).

Que consequências terá tido esta imigração no Noroeste? A pergunta é, por enquanto, irrespondível. É legítimo supor que se tratou de uma deslocação de importantes efectivos, pois de outra forma os imigrantes ter-se-iam diluído entre os autóctones e não teriam dado origem a unidades étnicas. Procedentes de uma área tecnologicamente mais avançada, Célticos e Túrdulos poderão ter introduzido o ferro e o torno de oleiro. Manuela Martins (1990:142 e 164) considera que tais inovações não se produziram no Noroeste antes de finais do séc. II a.C.. Armando Coelho F. da Silva (1986: 42) atribui a introdução do torno lento ao período de 200 - c. 140 a.C.. Poderemos remontar ainda as datas?

Ter-se-ão alguns Celtici estabelecido no vale do Cávado? No castro de S. Lourenço (Esposende) achou-se uma inscrição consagrada á Daea Sancta (SANTOS et allii, 1983:190). Ora este epíteto aplica-se a Atégina, deusa que teve em Turóbriga (na Betúria Céltica) um importante santuário e cujo culto se encontra difundido no Alentejo (ENCARNAÇÃO, 1984: 799-800). Será a ara de S. Lourenço um testemunho indirecto da presença dos Celtici no vale do Cávado?

Esta hipótese de fixação de Célticos no vale do Cávado talvez possa explicar a emergência dos castros agrícolas. Estes são povoados de baixa altitude, instalados em pequenas colinas que emergem da planície. Os exemplos portugueses conhecidos situam-se nos vales do Cávado e do Lima. No primeiro, Manuela Martins escavou o povoado do Lago e datou-o do séc. III a . C . (MARTINS , 1988 a); no vale do Lima, Brochado de Almeida atribuiu os castros agrícolas ao séc. I a.C. (ALMEIDA, 1990: 275). Aparentemente conflituosas, as duas cronologias poderão harmonizar-se, pois nada exige que o fenómeno da emergência dos castros agrícolas tenha sido umversalmente sincrónico. Para o explicar, Brochado de Almeida postula uma influência romana. A nosso ver, porém, os castros agrícolas podem interpretar-se como um fenómeno de intensificação da produção, exigida pelo crescimento demográfico. Ora, a pressão demográfica pode ter-se feito sentir mais cedo numas áreas do que noutras. Assim, a cronologia da Manuela Martins não é necessariamente conflituosa com a de Brochado de Almeida, como seria se recorrêssemos à hipótese de um estímulo externo (influência romana) para explicar o fenómeno. 
Se a imigração de Célticos e Túrdulos se deu no séc. III a.C., se alguns Célticos se estabeleceram no vale do Cávado, pode ter-se verificado um fenómeno de pressão demográfica responsável pela emergência dos castros agrícolas.

Talvez, a partir do séc. III a.C., o Noroeste tenha começado a recuperar do atraso sócio-económico.

A evolução do peso das joias parece, à primeira vista, testemunhar uma recuperação a partir de 500 a.C.. Com efeito, o peso das joias atribuíveis por Armando Coelho F. da Silva aos séculos IX e Vili é de 6195 gramas; o peso das peças de ourivesaria dos séculos VII e VI, 1058. O peso correspondente ao período de 500 a.C. a 140 a.C., 2450 gramas (Fig. 5). Considerando a duração do período entre 500 e c. 140 a.C. (muito mais longo que o anterior), não podemos, porém, falar de recuperação significativa. E não poderá uma boa parte da ourivesaria atribuível a 500 - c. 140 a.C. corresponder a peças contemporâneas da recuperação que presumimos a partir do séc. III a.C.? Infelizmente, é muito difícil precisar a cronologia das peças de ourivesaria atribuíveis ao período de 500 - c. 140 a.C..

Caracterizado, tecnicamente, pelo colapso da metalurgia do bronze e pelo desaparecimento da cerâmica fina típica do Bronze Final e, socialmente, pelo desaparecimento da integração política, o período que se inicia no séc. VII a.C. assiste ao desenvolvimento de uma cerâmica abundante em partículas de mica e tecnicamente homogénea (MARTINS, 1990: 135 e 142), embora possivelmente muito diversificada na decoração.

Armando Coelho F. da Silva elaborou um inestimável corpus dos motivos decorativos da cerâmica castreja (1990, ests. LXV a LXXVIII). Não investigou devidamente, porém, a cronologia dos motivos nem aprofundou o problema da sua eventual variabilidade de castro para castro ou de região para região. Serão necessárias muitas escavações para podermos entender se os temas variaram cronológica e localmente. A julgar pelo reduzido número de motivos presentes na cerâmica de $\mathrm{S}$. Julião (Martins, 1988b: 176) e do Barbudo (Martins, 1989:113), cada castro tinha o seu reportório limitado que foi repetido monotonamente durante séculos. Se os motivos divergem localmente, parece-nos legítimo concluir pela produção doméstica e pela ausência de comércio. A cerâmica será, assim, um reflexo da inexistência de integração política que parece caracterizar o período que se inicia no séc. VII a.C.. Se, por outro lado, a produção da cerâmica era uma tarefa feminina, a reduzida 
variedade de motivos em cada castro traduz a coesão social do povoado e a existência de uma regra de uxorilocalidade. Tensões sociais no interior de um castro exprimir-se-iam simbolicamente pela criação de motivos diferentes, como forma de sublinhar divergências familiares ou de linhagens. No caso da virilocalidade, isto é, se os homens permaneciam nos povoados de origem $\mathrm{e}$ as mulheres tomavam a residência dos maridos, encontrar-se-iam num castro mulheres de múltiplas proveniências; e, como cada uma traria os motivos aprendidos com sua mãe, deveria em cada castro encontrar-se uma considerável variedade de motivos. $\mathrm{O}$ reduzido reportório de $\mathrm{S}$. Julião e do Barbudo parece confirmar que a regra de casamento obrigava à deslocação do homem para junto dos sogros, e não o inverso.

A emergência de lugares centrais no fim do séc. II A. C.

A grande revolução da área galaico-lusitana deu-se nos fins do séc. II a.C., com a emergência de grandes povoados como Sanfins ou Briteiros, que funcionaram certamente como lugares centrais.

Parece-nos possível calcular de forma aproximada a população de Briteiros ou Sanfins. No primeiro caso, e admitindo que as habitações se circunscreviam à área cercada pela mais interior das muralhas (há todavia habitações entre a muralha interior e a média (CARDOZO, 1965, est. VI), temos uma superfície habitada de 3,75 hectares. Adoptando como regra de cálculo 300 habitantes por hectare, teríamos 1125 almas em Briteiros. Admitindo, por outro lado, uma necessidade de 60 ovicaprinos por habitante, teríamos uma população de 67.500 cabras ou ovelhas como exigência alimentar da citânia. Ora o território de 1 hora de Briteiros tem 1768 hectares. Calculando 3 cabeças de gado ovicaprino por hectare, o território de Briteiros alimentaria 5034 animais, número muito inferior ao definido como necessidade.

Quanto a Sanfins, a área de cerca de 7 hectares envolvida pela muralha 2 (SILVA, 1986: 45) permite calcular uma população de 2100 habitantes. Este cálculo pode ser confirmado por outra via. Numa área escavada de cerca de 1,5 hectare temos 100 casas redondas, isto é, cerca de $1970 \mathrm{~m} 2$ de área coberta (assumindo uma média de 5 metros de diâmetro para cada casa); numa superfície total de 6 hectares, supondo que a densidade das habitações fosse a mesma, teríamos $9193 \mathrm{~m} 2$ de área coberta. Ora à razão de $4,5 \mathrm{~m} 2$ de área coberta por habitante, isso daria 
uma população de 2042 habitantes, o que exigiria 122.520 cabeças de gado ovicaprino. Com 1923 hectares no território de uma hora, Sanfins não poderia criar mais de 5769 ovicaprinos.

Talvez os nossos cômputos de população pequem por excesso $\left({ }^{n}\right)$. Por outro lado, a população de Briteiros ou Sanfins não se alimentaria apenas de carne de ovicaprinos: praticaria também alguma forma de agricultura cerealífera (cujo cálculo, na ausência de cartas de capacidade dos solos, se toma difícil) e utilizaria os recursos da caça e da colheita de fmtos como a bolota e a castanha $\left({ }^{12}\right)$. De qualquer forma, a distância entre o número de animais necessários e o de animais que poderiam criar-se nos territórios é tão grande que não nos parece difícil admitir que Briteiros e Sanfins não poderiam sobreviver sem colheita de bens alimentares proporcionados por castros vizinhos e dependentes. Seriam, pois, lugares centrais.

Uma pergunta ocorre necessariamente : que fenómeno ou fenómenos explicam a emergência dos lugares centrais?

O modelo interpretativo aplicado por Frankenstein e Rowlands (1978) aos chefados hallstáticos do centro da Europa não parece transferível para o caso do Noroeste. Segundo estes autores, que adaptam ao caso

$\left.{ }^{\mathrm{n}}\right)$ As propostas de ratio entre área habitada/número de habitantes são muito diversas. Como é sabido, Renfrew propôs 300 habitantes por hectare para os povoados do Bronze Inicial do Egeu (RENFREW, 1972: 394). Leslie AlCOCK (1965:194) sugere 62,9 habitantes por hectare para o castro de Garn Boduan (Caernarvonshire), com casas de pedra circulares semelhantes às dos nossos castros do Noroeste. Esta ratio parece-nos excessivamente baixa. Alcock atribui 5,75 m2 de área coberta a cada habitante, o que é talvez excessivo. Por outro lado, uma grande área de Garn Boduan não está construída. Se adoptamos uma ratio de $4,5 \mathrm{~m} 2$ por habitante, a população do castro galês seria mais elevada do que a que propõe Alcock. Por outro lado, se deduzirmos a área intramuros não construída, a ratio da área construída eleva-se proporcionalmente, sem todavia atingir os 300 habitantes por hectare propostos por Renfrew. A nossa argumentação para propor uma densidade de 300 habitantes por hectare baseia-se na coincidência, que se verifica em Sanfins, entre o cômputo da população baseado naquela ratio e o cálculo do número de habitantes baseado em $4,5 \mathrm{~m}$ de área coberta por indivíduo .

(12) É evidente que a população não se alimentava exclusivamente de carne de ovicaprinos. A farinha de bolota poderia ser um contributo importante. Não temos, porém, dados para calcular o peso de farinha que se poderia obter num território eventualmente povoado de densos carvalhos. Por outro lado, poderia praticar-se uma agricultura cerealífera, embora de forma pouco intensiva. Assim, o nosso cálculo de capacidade de sustentação do território baseado exclusivamente na criação de gado ovicaprino é grosseiro.

Conimbriga, 31 (1992), 39-71 
hallstàtico uma teoria de economia política de Meillassoux, o poder político desenvolve-se a par com o comércio de bens de prestígio procedentes do estrangeiro; por outras palavras, usando a terminologia de Wallerstein, o poder político numa área periférica desenvolve-se através do comércio com uma área central, que, no caso da Europa hallstàtica, foi o mundo greco-etrusco. O comércio externo era monopolizado pelos chefes hallstáticos e os bens de prestígio (no caso vertente, o vinho e a cerâmica grega importados, bem como as joias de ouro e as carroças de fabrico local) eram distribuídas pelos chefes (suzeranos) a outros chefes menores que se transformavam em vassalos, criando assim um sistema político piramidal.

A importância do comércio externo no Noroeste, nos fins do séc. II a.C., parece reduzida. É certo que entre 200 e 140 a.C., segundo Armando Coelho F. da Silva (1986: 42), se verificam algumas importações de campaniense. A importação de ânforas pode ser anterior a Augusto (FABIÃO, 1989: 111) mas possivelmente não remonta ao séc. II a.C.. O comércio externo parece muito restrito e insuficiente para provocar a emergência de lugares centrais.

Se os chefes não surgiram para organizar um comércio de bens de prestígio alógenos, poderão ter aparecido para regular a circulação de bens regionais? Essa actividade reguladora pressupõe a diversidade ecológica. Tal diversidade conduziria à especialização produtiva dos povoados, cada um gerando os seus frutos, de acordo com as aptidões das suas terras; e esta especialização traria como consequência a necessidade de trocas que despejassem uns povoados dos excedentes e abastecessem outros daquilo que lhes minguava. Ora, os castros do Noroeste não apresentam essa diversidade ecológica; quando muito, poderíamos admitir um comércio de sal entre povoados da beira-mar e outros interiores.

Um domínio onde haveria diversidade seria o dos recursos mineiros, pois nem em toda a parte havia jazidas metalíferas; mas não parece que, no séc. II a.C., tenha havido intensificação da produção metalúrgica e daí, necessidade de organizar o comércio.

Assim, não podemos, aparentemente, explicar o aparecimento dos chefes pela necessidade de instaurar e regular a circulação de bens de subsistência ou de metais.

O panorama do Nordeste alentejano parece diferente. Analisando um restrito caso regional, Teresa Gamito (1988: 159) sugeriu a especialização dos povoados: uns, como Vaiamonte, dominavam bons solos 
agrícolas; outros, como Segóvia, jazidas de minério. Entre os povoados estabeleceram-se certamente redes de intercâmbio que poderiam explicar a emergência de chefes. $\mathrm{O}$ mecanismo eventualmente válido para o Nordeste alentejano não parece, porém, transponível para o Noroeste nem, aliás, para as Beiras, embora tenhamos de reconhecer que a investigação está demasiadamente atrasada para podermos pronunciar-nos com segurança num problema que deve permanecer aberto.

Que explicação poderemos então sugerir para a emergência de lugares centrais e de chefes no Entre Douro e Minho?

Em 137 a.C., Décimo Júnio Bruto realiza a sua expedição ao Noroeste. Apesar da vitória retumbante que lhe mereceu o cognome de Calaico, a expedição não parece ter sido seguida de ocupação efectiva; mas o perigo de novos ataques era agora iminente. Talvez a necessidade de organizar a defesa tenha sido o motor da integração política dos povoados castrejos sob a égide de alguns lugares centrais e dos seus correspondentes chefes.

A integração política poderá ter sido, por outro lado, o factor que determinou a consciência étnica, isto é, a consciência das identidades e diferenças dos povos. O quadro dos populi pré-romanos do Noroeste, deduzível da História Natural de Plínio e complementado por algumas fontes epigráficas, foi traçado por Tranoy (1981: 45-74), que procurou situá-los geograficamente. Quando e como se formaram esses populi, isto é, quando é que se gerou a consciência étnica? O fenómeno está certamente relacionado com a integração política. Podemos perguntarmos o que veio primeiro: a consciência étnica ou a integração política? Cremos que a integração política.

Na Beira Baixa e na Beira Transmontana, isto é, na área nuclear dos Lusitanos, não temos notícia de grandes castros que possam ter desempenhado funções de lugares centrais. É certo que o nosso conhecimento da Idade do Ferro nesta área é praticamente nulo. Não temos um inventário de castros comparável ao de Armando Coelho F. da Silva, nem escavações como as que se têm realizado no Entre Douro e Minho. Admitamos, porém, a inexistência de lugares centrais, que as prospecções ainda não revelaram. Por que razão é que eles não surgiram, se a região conheceu a mesma ameaça romana que Entre Douro e Minho?

Antes de mais diremos que as estratégias foram diferentes: enquanto os Calaicos deliberaram defender-se dos Romanos no seu próprio território, os Lusitanos decidiram atacá-los fora da sua região. 
Mas porquê essa diferença de estratégia? A razão poderá ser histórica: os Lusitanos tinham uma longa tradição de guerra fora da fronteira étnica.

O estado de guerra endémica a que Estrabão alude parece confirmado, para os Lusitanos, por outras fontes históricas. Esta guerra dos Lusitanos não era uma luta interna entre povoados da mesma etnia; era uma guerra exterior, dirigida contra a Turdetânia e a Carpetânia, que os Lusitanos atacavam em correrias possivelmente anuais. Temos numerosas notícias dessas correrias ou raids desde 194 a.C..

Que função material ou social teria esta guerra? Não era uma guerra pela conquista de novos territórios, visto que os Lusitanos nunca se estabeleceram na Bética e sempre regressavam às suas terras. Corresponderia a guerra a uma captura de meios de subsistência e seria exigida pela insuficiência da produção em terra própria? $\mathrm{Na}$ ausência de um inventário dos castros, que seria a condição mínima indispensável para podermos formular alguma hipótese sobre os quantitativos da população e sobre a possibilidade ou não de esta viver dos seus recursos, a pergunta é, de momento, irrespondível. Permitimo-nos todavia lançar alguma dúvida sobre a função material da guerra, isto é, sobre a explicação da guerra como forma de capturar bens de subsistência. A táctica parece ter sido a da guerrilha, dificilmente compatível com a captura de gado e de cereais cujo transporte a longa distância atrasaria a marcha da guerra a ponto de a tornar pouco segura. Teria então a guerra uma função meramente social?

Admitamos uma sociedade que favorecia a audácia e a bravura, uma sociedade que tinha por valores morais primitivos ou basilares a coragem, o denodo. A demonstração dessas qualidades seria uma forma de adquirir status, uma abonação na altura de procurar casamento: nenhuma mulher quereria desposar quem se não pudesse reclamar de feitos de bravura.

Se os valores morais da sociedade podem manter ou perpetuar a guerra, mesmo que esta não cumpra funções materiais, esses valores não criam a guerra. Só numa sociedade guerreira se pode gerar a moral da valentia. Aparentemente, temos um círculo vicioso que explica a guerra pela ideologia e esta pela guerra. Como sair do círculo?

A guerra pode ser, para uma população primitiva, uma maneira de travar o crescimento demográfico. Mecanismos mais óbvios são, evidentemente, o aborto e o infanticídio; mas é sabido que há outros mecanismos. Há, pelo menos, o de prolongar o aleitamento materno, que impede a ovulação e, por consequência, a gravidez (HARRIS, 1990: 33). E há o 
mecanismo cultural de adiamento da idade núbil: quanto mais velhos forem os cônjuges no momento do enlace, menor será o número provável de filhos.

Ora, a guerra endémica dos Lusitanos pode ter cumprido essa função social de adiamento da idade núbil: os homens não casariam sem terem demonstrado primeiro o seu valor. $\mathrm{O}$ mecanismo não funcionaria, evidentemente, sem um idêntico retardamento da nubilidade feminina ou sem um infanticídio preferencialmente feminino, infanticídio frequentemente praticado por sociedades guerreiras (DIVALE e HARRIS, 1976).

Nesta perspectiva, a guerra terá funcionado inicialmente como mecanismo de contenção do crescimento demográfico, mecanismo esse surgido da escassez de bens alimentares; uma vez instituída, terá criado uma ideologia de bravura responsável pela sua perpetuação. $O$ que mudou, desde os inícios do séc. II a.C., não foi a ideologia ou a função social da guerra, mas o inimigo: de uma luta contra Turdetanos da Bética e Carpetanos, passou-se a uma guerra contra os Romanos.

Não aclarámos inteiramente, porém, até agora, porque é que não surgiram lugares centrais no território dos Lusitanos. A criação de lugares centrais pressupõe a permanência do poder nos mesmos lugares e a instituição de hierarquias duradoiras de povoamento. Ora, talvez uma ideologia de igualdade, ardorosamente defendida, tenha conduzido, entre os Lusitanos, à transiência dos chefes que conduziam a guerra. Viriato foi o único que manteve o poder durante vários anos seguidos. Mesmo assim, temos notícia da existência de outros chefes durante o período das guerras lusitanas. Viriato não conseguiu unir todas as forças dos Lusitanos. Os do Alentejo, como nos revelam as fontes históricas, combatiam sob as ordens de Cúrio e Apuleio. Se a paz negociada em 140 a.C. por Fábio Máximo Serviliano (paz que reconheceu ao chefe lusitano o título de amicus populi Romani) tivesse sido mantida, teríamos talvez assistido ao aparecimento de um lugar central aí onde Viriato tivesse decidido fixarse. Mas a paz foi logo rompida, e Viriato assassinado em 139 a.C.. A ideologia da igualdade, eventualmente assente numa falta de intercâmbio económico entre os povoados, não permitiu a emergência de chefes permanentes e de uma hierarquia de povoamento sob a égide de alguns lugares centrais. 
A conquista do Noroeste e a sua reorganização administrativa

Se a emergência de lugares centrais no Entre Douro e Minho se explica por uma necessidade de organizar a defesa, talvez ela tenha, ao contrário, facilitado a conquista.

As fontes clássicas são mudas quanto a operações militares no território actualmente português a norte do Douro. $\mathrm{O}$ único facto referenciado posteriormente à expedição de Décimo Júnio Bruto é a tomada de Cale por Perpena em 74 a.C. (Tranoy, 1981: 130).

A referência de Servius, Ad. Aen. (Cales civitas est Campaniae... est et in Gallaecia, quam Sallustius captam a Perperna commemorat) pode aduzir-se como argumento a favor da identificação de Cale com o Porto. Que importância teria Cale que justificasse a conquista? Poderia ser um port of trade por onde se exportaria o ouro de Vila Pouca de Aguiar, transportado ao longo do eixo do rio Tâmega e, depois, do Douro. Cale seria igualmente um porto importador de produtos mediterrânicos (REAL et alii, 1985-1986: 28).

A ausência de referências literárias à história militar no Entre Douro e Minho posteriormente à tomada de Cale poderá tomar-se como indício de uma conquista fácil da região? Será o registo arqueológico tão omisso quanto as fontes literárias?

Schulten sugeriu a instalação, no local da futura Bracara Augusta, de uma legião comandada por Públio Carisio ao tempo das campanhas do primeiro imperador no Noroeste peninsular. Nada, porém, confirma tal hipótese (TRANOY, 1981b: 109). Apenas o testemunho de alguns tesouros monetários sugere que a província de Entre Douro e Minho foi palco de guerra no tempo de Augusto. Temos, em primeiro lugar, os tesouros de Monte Mozinho (Penafiel) e Guiães (Vila Real), que terminam com moedas de 32-31 a.C. (CENTENO, 1987: 193). Depois, os dois tesouros de Alvarelhos, com séries que terminam em 27 a.C.. Um deles, além de denaários, continha duas bolas de prata com a palavra CAESAR grafitada (CENTENO, 1987: 35 e 212). Aparentemente, estas bolas destinavam-se à cunhagem, em campanha, de denários para pagamento do soldo as tropas e terão sido roubadas a uma legião. Finalmente, o tesouro de Sanfins, embora contendo uma moeda de 25-23 a.C. (CENTENO, 1987: 50), também se pode relacionar com as guerras do Noroeste.

Seja como for, a ausência de testemunhos literários da guerra parece indício de uma integração fácil do território actualmente português a 
norte do Douro. Terão os chefes, cuja existência presumimos, aceitado facilmente o domínio romano a troco de uma manutenção no poder?

Quaisquer que tenham sido os sucessos da conquista, terá Augusto organizado administrativamente o Noroeste segundo o modelo das civitatesl O texto de Plínio III 4, 28 fala das 24 civitates do conventus Bracarum. Ora é opinião corrente que Plínio se serviu, para compor os parágrafos sobre geografia política da Hispânia, de listas ou formulae da época de Augusto. Assim, as civitates do Entre Douro e Minho remontariam ao primeiro imperador.

Contra esta opinião podemos aduzir três argumentos. Primeiro, na região de Lugo, no séc. I d.C., encontramos principes à frente dos populi. Vecco (?), filho de Vecius, príncipe dos Co[pori (ARIAS VILAS et alii, 1979:60-61) eNiger, fillho de Clutosius, príncipe dosAlbiones (ALBERTOS FIRMAT, 1975:42). Segundo, embora Plínio se tenha servido àt formulae augustanas, pode ter actualizado o seu texto no que concerne ao Noroeste, de cuja administração tinha conhecimento directo: as civitates de que fala poderiam ser uma criação flaviana. Terceiro, Plínio nem sempre usa o termo civitas num sentido técnico, como se documenta com o passo III 4,26 .

O que nos importa, porém, não é tanto o nome que terá sido dado por Augusto às circunscrições (pode ter sido o de civitates), como o princípio que norteou a divisão administrativa e o tipo de governo adoptado. Talvez Augusto tenha criado circunscrições correspondentes aos antigos populi, escolhido os antigos lugares centrais (ou alguns deles) como capitais das novas unidades administrativas e confiado o governo a principes vitalícios, se não mesmo hereditários.

Este sistema exigiria alguma forma de tutela e para a garantir terão sido criados os centros urbanos de Bracara Augusta, Lucus Augusti e Asturica Augusta. Terá sido administrativa a razão determinante destas fundações, que, desde o início , porém, terão desempenhado funções económicas como centros produtores e nodais de um comércio de bens importados, redistribuídos a partir delas.

Será possível reconstituir a posição geográfica dos oppida ou castella que funcionaram como capitais das circunscrições administrativas augustanas? Talvez, através das estátuas de guerreiros galaicos.

As estátuas são provavelmente representações de chefes ou principes, atribuíveis ao séc. I d.C., mas pré-flavianas. Assim, a sua localização é um testemunho indirecto das residências dos chefes pré-flavianos. 
Armando Coelho F. da Silva (1986: 305-309) publicou um inventário dos guerreiros galaicos.

Se cartografarmos os lugares de achado (Fig. 6), teremos no Entre Douro e Minho dez lugares centrais e três no eixo do Tâmega. Temos, por outro lado, quatro populi cuja situação no Entre Douro e Minho é segura (Seurbi, Leuni, Bracari e Callaici) e três cuja localização é provável (Nemetati, Luanci e Lubaeni). A probabilidade de localização destes últimos no Entre Douro e Minho deduz-se do facto de não estarem citados no Padrão dos Povos de Chaves (CIL II 2477), que menciona as civitates mais interiores.

Não há coincidência entre o número de estátuas e o número de populi; mas Plínio indica 24 populi no conventus bracaraugustanus e nomeia apenas 21; como se chamariam os restantes e onde é que ficariam situados? Por outro lado, não é de excluir a hipótese de ter havido transferências de localização de lugares centrais.

Plínio IV, 112 situa entre Minho e Lima os Leuni e os Seurbi. Armando Coelho F. da Silva (1986: 280) propôs a localização dos primeiros a montante e dos Seurbi a juzante. Cendufe e S. Paio de Meixedo seriam as respectivas capitais.

O lugar central dos $\mathrm{Br}$ acari seria Roriz (Barcelos) ou S. Julião (Vila Verde), ambos no Vale do Cávado; Monte Mozinho, o dos Callaeci, que Tranoy (1981: 65) situa, com bons fundamentos, imediatamente a norte do Douro.

Quanto aos Nemetati, Tranoy (1981: 72) sugeriu a sua vizinhança de Bracara Augusta mas Armando Coelho F. da Silva (1986, est. X) preferiu situar no Ave a sua capital, Valabriga.

Para os Luanci e Lubaeni não temos, por enquanto, qualquer proposta; mas poderiam perfeitamente ficar situados na província de Entre Douro e Minho.

Dos três lugares situados no eixo do Tâmega, um deles (talvez mais provavelmente Outeiro Lezenho) poderá ter sido a capital dos Tur odi, posteriormente deslocada para Aquae Flaviae. Outro, o dos Naebisoci, visto que a inclusão deste nome na coluna de Chaves (CIL II2477) deixa supor uma proximidade geográfica. Não concordamos com Armando Coelho F. da Silva, que os situa nas margens do Neiva (1986: 283).

Em Santa Comba (Refojos de Basto) encontrou-se uma estátua de guerreiro com inscrição na caetra. Esta inscrição recorda um populus, Abianis, Albinis ou Labinis (SILVA, 1986:285, nota 284 e 308), que não se acha mencionado por Plínio. É necessário, porém, recordar que dos 24

Conimbriga, 31 (1992), 39-71 
populi ou civitates atribuídos por Plínio ao conventus Bracarum, apenas conhecemos, através de fontes literárias ou epigráficas, 21. Há, portanto, 3 populi desconhecidos. Poderá um deles ser o dos Albinis, e poderemos situá-lo em Terras de Basto, com centro em Santa Comba? Poderá outro dos povos desconhecidos situar-se em S. Martinho de Britelo?

A localização da estátua de S. Jorge de Vizela suscita dúvidas. Com efeito, foi pela primeira vez registada em 1884 por Martins Sarmento, que a viu no adro da igreja matriz daquela freguesia. Ignora-se de onde procede. De algum castro vizinho?

A emergência de lugares centrais, cuja identificação aqui discutimos, talvez com risco de quebrar a lógica do discurso, parece o facto mais relevante dos fins do séc. II ou dos inícios do I a.C., marcando o regresso a uma complexidade social que havia diminuído entre os séculos VII e II.

Segundo Armando Coelho F. da Silva (1986:43), a emergência dos grandes povoados terá sido acompanhada pelo abandono de castros menores. Este fenómeno de concentração populacional parece-nos viável, embora careça de confirmação através de escavações. Se, como sugerimos, os lugares centrais não podiam sobreviver sem tributarem povoados menores, a manutenção destes era essencial. Tal manutenção não é, porém, incompatível com uma redução da população dos castros menores. Por outro lado, como Manuela Martins sugeriu (1990: 150), o abandono de castros menores, se efectivamente se verificou, pode estar relacionado com a multiplicação dos castros agrícolas que, pelo menos no vale do Lima, como acima vimos, parecem datar do séc. I a.C..

Nos povoados maiores surgiu certamente uma classe de artífices profissionais, responsáveis pela adopção de inovações técnicas cuja difusão para outros castros menores é, por enquanto, impossível de avaliar. A partir de fins do séc. II a.C. são notórias: a utilização do torno de oleiro e a melhoria do processo de cozedura da cerâmica, com fornos oxidantes (SILVA, 1986: 125); a adopção da mó giratória (SILVA, 1986: 47); o uso do ferro (SILVA, 1986: 62 e 171). Por outro lado, criaram-se novas formas cerâmicas (MARTINS, 1990: 155-163).

Os contactos com o mundo romano, no período entre os finais do séc. II a.C. e as campanhas de Augusto, manifestam-se pela importação de ânforas vinárias de tipo Dressel 1 e de cerâmica campaniense (SILVA, 1986: 136). O volume dessas importações parece, porém, reduzido e as ânforas poderão ter sido importadas apenas a partir dos finais do séc. I a.C. (MARTINS, 1990: 149). Dificilmente poderemos tomar o comércio 
externo como factor decisivo no desenvolvimento da cultura castreja entre os finais do séc. II a.C. e a época de Augusto.

\section{De Augusto aos Flávios}

A integração administrativa do Noroeste no império romano não trouxe o abandono dos castros. $\mathrm{Na}$ área do vale do Cávado estudada por Manuela Martins (1990), dos 44 povoados fortificados reconhecidos, 19, isto e, 43\%, foram romanizados. Em Santo Ovídio (Fafe), o período de Augusto "assinala uma grande vitalidade do povoado, não só representada nas numerosas construções realizadas, como também pelo desenvolvimento da metalurgia e pela presença de moedas e materiais de importação" (MARTins, 1991:89). As moedas, a sigillata e os vidros descobertos em alguns castros pressupõem não só uma ocupação como também um certo poder de compra dos habitantes. A citânia de Briteiros, por exemplo, proporcionou vidros de luxo da primeira metade do séc. I d.C.: cinco fragmentos de taças millefiori e um de jarro decorado com grânulos de vidro em relevo, tipo extraordinariamente raro, do qual se conhecem poucos exemplares no mundo romano (ALARCÃo, 1963). As ombreiras e vergas decoradas das portas, bem como outros elementos arquitectónicos, que Calo Lourido (1991: 769) atribui, talvez com razão, ao período júlio-claudiano, denunciam investimentos para traduzir, no aspecto exterior das casas, o status dos habitantes principais. Não podemos, assim, imaginar os castros despovoados de elites no período júlio-claudiano.

Os meados do séc. I d.C. parecem, todavia, representar um marco histórico importante. Segundo Armando Coelho F. da Silva, Sanfins, Âncora e Romariz (1986: 47, 50 e 53) entram em franco declínio. O povoado do Lago parece ter sido abandonado na mesma altura (MARTINS, 1990:150). Em S. Julião e no Barbudo, Manuela Martins observa, a partir dessa época, a divulgação de cerâmica comum romana; não temos, porém, nos dois castros, materiais importados que nos dêem testemunho de um poder de compra elevado, como verificamos em Briteiros na primeira metade do século (MARTINS, 1988b: 215 e 221; MARTINS, 1989: 117-118).

Temos, a partir de meados do séc. I d.C., um processo de romanização mais intensa de alguns castros associado à deserção (parcial ou total) de outros.

O processo de deserção pode ilustrar-se com o caso de Santo

Estevão da Facha (Ponte de Lima) (Almeida et alii, 1981). O castro foi 
ocupado pelo menos até à segunda metade do séc. I d.C., pois nele se encontrou "cerâmica bracarense" (ALMEIDA et alii, 1981: 36). A ausência de materiais datáveis posteriores deixa-nos supor um abandono nessa epoca, até uma reocupação que terá tido lugar na Alta Idade Média. Ora, a nascente e sudeste do castro, no limite do seu território de uma hora, observam-se numerosos locais com tegulae. Aparentemente, correspondem a modestos casais. A distância média entre as tegulae, no conjunto a nascente, anda pelos 145 metros, o que nos permite calcular prédios rústicos de cerca de 2 hectares, suficientes para prover ao sustento de uma família nuclear, que poderia aliás subsistir não só das colheitas em terras próprias como de algum gado apascentado em terrenos de propriedade colectiva. Aparentemente, neste caso, a população desertou do castro para vir estabelecer-se em casais dispersos no âmbito do anterior território de uma hora. A deserção pode ter começado no tempo de Augusto, época à qual C. A. Brochado de Almeida (1990: 62) atribui uma casa redonda de estilo castrejo situada a 377 metros do castro.

\section{A sobrevivência dos castros}

O caso de Santo Estêvão da Facha documenta o abandono de um castro e a dispersão da população por casais em terras mais baixas ao longo do séc. I d. C. Não podemos, porem, generalizar o exemplo. Os materiais do séc. II d. C. encontrados em alguns povoados fortificados (designadamente em S. Julião, vid. MARTINS, 1988b: 221-222) dão testemunho da sobrevivência de alguns castros, romanizados. O estudo da circulação monetária até finais do séc. II d. C. realizado por Rui Centeno (1987) demonstra a existência de numismas do séc. II em diversos castros. Assim, alguns povoados fortificados sobreviveram pelo menos naquele século.

Parecem ser mais abundantes os materiais do séc. IV d.C. Terá havido continuidade de ocupação ou reocupação no Baixo Império? Inclinamo-nos mais para a hipótese da continuidade, por não vermos, no séc. IV, razões determinantes para um movimento de reocupação.

O fenómeno da deserção dos castros parece ter sido, assim, gradual, desde a época de Augusto pelo menos até um avançado séc. II d. C. Um abandono total provavelmente nunca se verificou. Não é certo que, ainda no séc. V d.C., Idácio de Chaves (Chronicon, 49 e 91) fala de castellai 
Os castros continuadamente ocupados, provavelmente, manifestavam níveis diferentes de romanização. É possivel que muitos tenham permanecido marginalizados, com reduzida assimilação dos benefícios da civilização romana. A simples recordação do teor de vida de muitas aldeias serranas do nosso tempo ajuda-nos a compreender a distância que, na época romana, pode ter mediado entre uma cidade como Bracara Augusta ou Aquae Flaviae e um castro à margem das vias principais.

Desde o séc. $\mathrm{X}$ a. C. ao V d. C. decorrem quinze séculos. Durante eles assistimos primeiro a uma integração política (entre os séculos $\mathrm{X}$ e VIII a.C.), depois uma desintegração (de inícios do séc. VII aos finais do II a.C.), seguidamente uma nova concentração com a formação de etnias e, a partir do reinado de Augusto, a uma deserção que não foi total, porque no séc. V. d. C. ainda havia populações que viviam em castella. Poderemos falar de uma cultura castreja de tão longa duração? Será mais correcto falar apenas de uma forma de habitat que permanece apesar das transformações económicas e socioculturais?

\section{BIBLIOGRAFIA}

AlARCÃo, Jorge de: AlarCÃo, Adília Moutinho de, 1963: "Vidros romanos do Museu de Martins Sarmento", Revista de Guimarães, 73 (1-2), 175-209.

AlcocK, Leslie, 1965: "Hillforts in Wales and the Marches", Antiquity, 39 (155), 184-195.

AlmeidA, Carlos A. Brochado de, 1990: Proto-história e romanização da bacia inferior do Lima, Viana do Castelo.

Almeida, Carlos Alberto F. de; Soeiro, Teresa; AlmeidA, Carlos A. Brochado de; BAPTistA, António José, 1981: Escavações arqueológicas em Santo Estevão da Facha, Ponte de Lima.

ARIAS VILAS, F,; LE ROUX, P.; TRANOY, A., 1979: Inscriptions romaines de la province de Lugo, Paris.

ARnaut, José Morais; GAmito, Teresa Júdice, 1974-1977: "Cerâmicas estampilhadas da Idade do Ferro do Sul de Portugal. I. Cabeça de Vaiamonte Monforte", O Arqueólogo Português, 3. â serie, 7-9, 165-202.

BAticle, Yves, 1974: L'élevage ovin dans les pays européens de la Mediterranée occidentale, Paris.

BouloumiÉ, Bernard, 1988: "Le symposium gréco-étrusque et l'aristocratie celtique", in Les princes celtes de la Mediterranée (Rencontres de VEcole du Louvre), Paris, 343-384. 
CAlo Lourido, Francisco, 1991: A plástica da cultura castrexa galego-portuguesa, tese de doutoramento policopiada apresentada na Faculdade de Xeografia e Flistoria da Universidad de Santiago de Compostela.

Cardozo, Mário, 1972: Catálogo do Museu de Martins Sarmento. Secção de epigrafia latina e de escultura antiga, Guimarães.

Centeno, Rui M. S., 1987: Circulação monetária no Noroeste deHispânia até 192, Porto.

CoElho, Inocêncio Seita, 1982: Economia dos sistemas agro-pastoris na Serra da Estrela, Lisboa.

Coelho, José, 1941: Memórias de Viseu (Arredores). I. A freguesia de Salvador e extinto concelho do Barreiro e notas toponímicas de Viseu e concelhos limitrofes, Viseu.

Curado, Fernando Patrício, 1984: "Uma nova esteia do Bronze Final na Beira Alta (Baraçal, Sabugal - Guarda)", Arqueologia, 9, 81-85.

Curado, Fernando Patrício, 1986: "Mais uma esteia do Bronze Final na Beira Alta (Fóios, Sabugal - Guarda)", Arqueologia, 14, 103-109.

Divale, William T.; HARRIS, Marvin, 1976: "Population, warfare and the male supremacist compì ex”, American Anthropologist, 78, 521-538.

DOPICO CAINZOS, M.- Dolores, 1986: "Los conventus iuridici. Origen, cronologia y naturaleza historica", Gerión 4, 265-283.

ENCARNAÇÃO, José d', 1984: Inscrições romanas do conventuspacensis, Coimbra.

ETIENNE, Robert, 1958: Le culte impérial de la Péninsule Ibérique dAuguste à Dioclétien, Paris .

FABĨ̃O, Carlos, 1989: Sobre as ânforas do acampamento romano da Lomba do Canho (Arganil), Lisboa.

Fernández CAStro, María Cruz, 1988: Arqueologia protohistórica da Península Ibérica (siglos X a Vili a. C. ), Madrid.

FranKenstein, Susan; RowlandS, M. J., 1978: "The internal structure and regional context of Early Iron Age society in south-western Germany", Bulletin of the Institute of Archaeology of London, 15, 73-112.

GAMITO, Teresa Júdice, 1988: Social complexity in southwest Iberia, 800-300 a.C.. The case ofTartessos, Oxford (BAR International Series, 439).

GAmito, Teresa Júdice, 1991: "A introdução da metalurgia do ferro no Sudoeste peninsular (com base nas dataçôes de radiocarbono) ", Actas das IVJornadas Arqueológicas, Lisboa, Associação dos Arqueólogos Portugueses, 299-304.

GIRÃO, Aristides de Amorim, 1933: Esboço de uma carta regional de Portugal, Coimbra.

Gomes, Mário Varela; MonteIro, Jorge Pinho, 1977: "Las esteias decoradas de Pomar (Beja - Portugal). Estudio comparado", Trabajos de Prehistoria, 34, 165-204.

GophnA, Ram; LiPhSChitZ, Nili; Lev-YAdun, Simcha, 1986-87: “Man's impact on the natural vegetation of the central coastal plain of Israel during the Chalcolithic period and the Bronze Age", Tel Aviv, 13-14(1), 71-84.

Conimbriga, 31 (1992), 39-71 
Guerra, Amílcar; Fabiáo, Carlos; Senna-Martínez, J. C, 1989: “O Cabeço do Crasto de São Romão, Seia. Alguns resultados preliminares das campanhas 1(985) a 3(987)", Actas do I Colóquio Arqueológico de Viseu, Viseu, 189-234.

HalsteAD, Paul, 1981: "Counting sheep in Neolithic and Bronze Age Greece" in Hodder, Ian; ISAAC, Glynn; HAMmOND, Norman, Pattern of the Past Studies in honour of David Clarke, Cambridge, 307-339.

HARRIS, Marvin, 1990: Canibais e reis, Lisboa.

HASSAN, Fekri A., 1982: "Demographic archaeology" in SCHIFFER, Michael B., Advances in archaelogical method and theory. Selections for students from volumes 1 through 4, New York, 225-279.

LEVY, Janet E., 1979: "Evidence of social stratification in Bronze Age Denmark", Journal of Field Archaeology, 6, 49-56.

LeVy, Janet E., 1982: Social and religious organization in Bronze Age Denmark. An analysis of ritual hoard finds, Oxford.

LOPEZ-CUEVILlAS, Florentino, 1989: La civilización céltica en Galicia, Madrid.

MARTINS, Manuela, 1988a: 0 povoado fortificado do Lago, Amares, Braga.

Martins, Manuela, 1988b: A citânia de S. Julião, Vila Verde. Memória dos trabalhados realizados entre 1981-1985, Braga.

Martins, Manuela, 1989:0 castro do Barbudo, Vila Verde. Resultados das campanhas realizadas entre 1983 e 1985 , Braga.

MARTINS, Manuela, 1990: Opovoamento proto-histórico e a romanização da bacia do curso médio do Cávado, Braga.

MARTINS, Manuela, 1991: O povoado de Santo Ovídio (Fafe): resultado dos trabalhos realizados 1980-1984, Braga.

ReAL, Manuel Luís; TÁvorA, Maria José; OsóRIO, Maria Isabel Pinto; TeIXeIrA, Filipe Fernando, 1985-86: "Escavações arqueológicas no Morro da Sé", Boletim Cultural da Câmara Municipal do Porto, 2.- série, 3-4, 7-44.

RENFREW, Colin, 1972: "Patterns of population growth in the prehistoric Aegean", in UCKo, P.; Tringham, R.; Dimbleby, Man, settlement and urbanism, Londres, 383-399.

Santos, Luciano dos, Le Roux, Patrick; TRanoy, Alain, 1983: "Inscrições romanas do Museu Pio XII em Braga", Bracara Augusta, 83-84, 183-205.

SiLva, Armando Coelho F. da, 1980: "Organizações gentílicas entre Leça e Ave", Portugália, nova série, 1, 79-80.

Silva, Armando Coelho F. da, 1983: "As tesserae hospitales do Castro da Senhora da Saúde ou Monte Murado (Pedroso, V. N. Gaia). Contributo para o estudo das instituições e povoamento da Hispânia antiga", Gaya, 1, 9-26.

Silva, Armando Coelho F. da, 1984: "Aspectos da proto-história e romanização no concelho de Vila Nova de Gaia e problemática do seu povoamento", Gaya, 2, $39-58$.

Silva, Armando Coelho F. da; SILVA, Celso Tavares da; LoPES, António Baptista, 1984: "Depósito de fundidor do final da Idade do Bronze do castro da Senhora da Guia (Baiões, S. Pedro do Sul, Viseu)", Lucerna. Número extraordinário. Colectânea de estudos de homenagem a D. Domingos de Pinho Brandão, 73-109. 
Silva, Armando Coelho F. da, 1986: A cultura castreja no Noroeste de Portugal, Paços de Ferreira.

TranoY, Alain, 1981a: La Galice romaine. Recherches sur le nord-ouest de la péninsule ibérique dans VAntiquité, Paris.

TRANOY, Alain, 1981b: "Romanisation et monde indigène dans la Galice antique: Problèmes et perspectives", Primera Reunión Gallega de Estudios Clasicos, Santiago-Pontevedra, 2-4 juliol979, Santiago de Compostèla, 105-121.

UntermanN, Jürgen, 1965: Elementos de un atlas antroponimico Ae la Hispania antigua, Madrid.

Conimbriga, 31 (1992), 39-71 


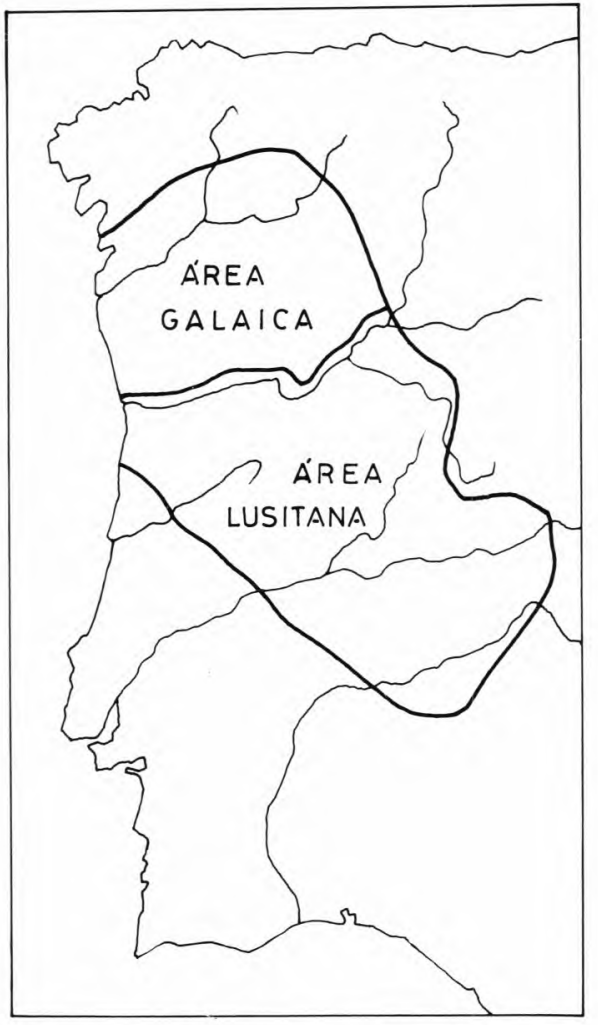

FIG. 1 - Áreas linguísticas, segundo Untermann. 


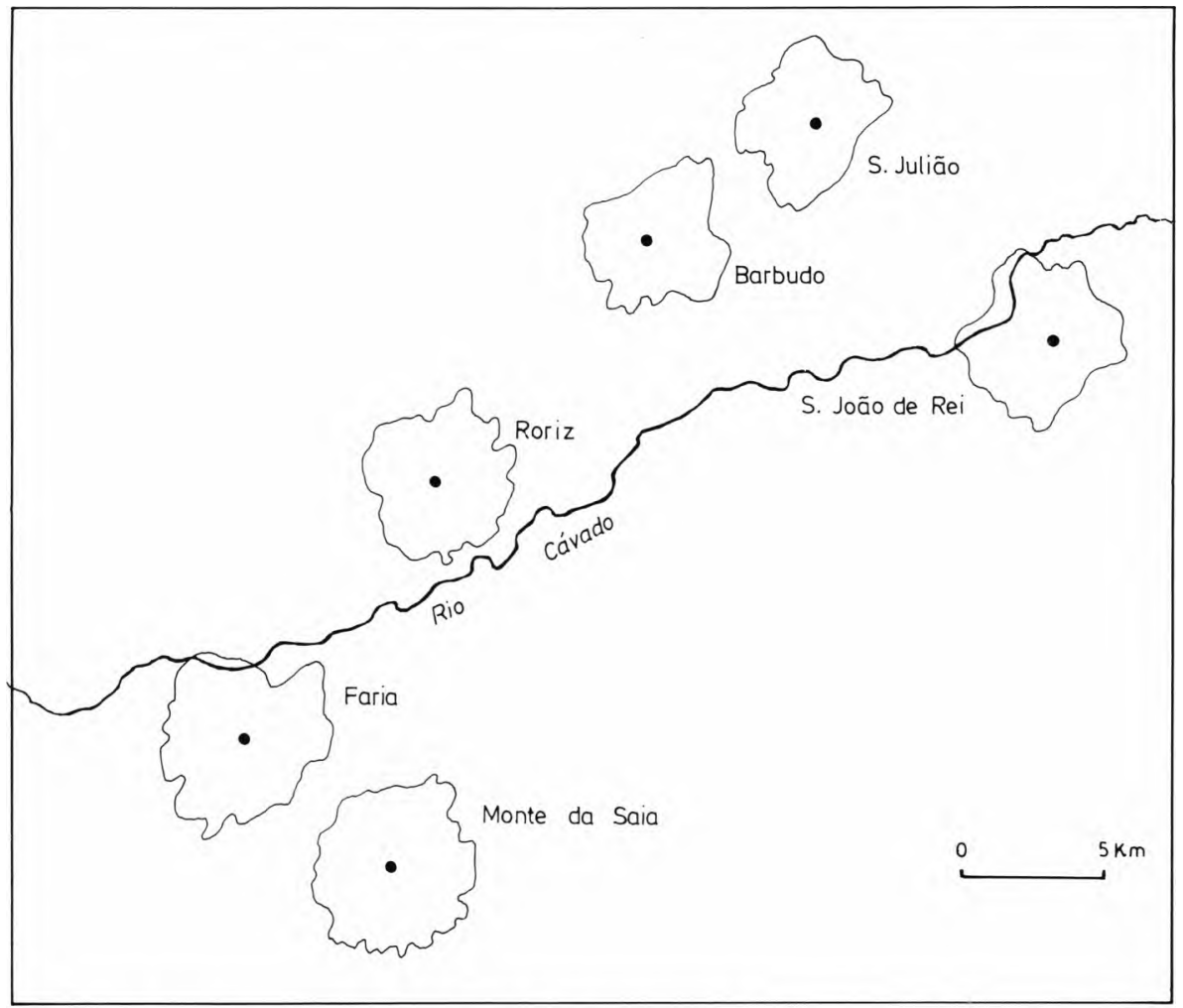

FIg. 2 - Povoados do Bronze Final no curso médio do Cávado e seus territórios, segundo Manuela Martins. 


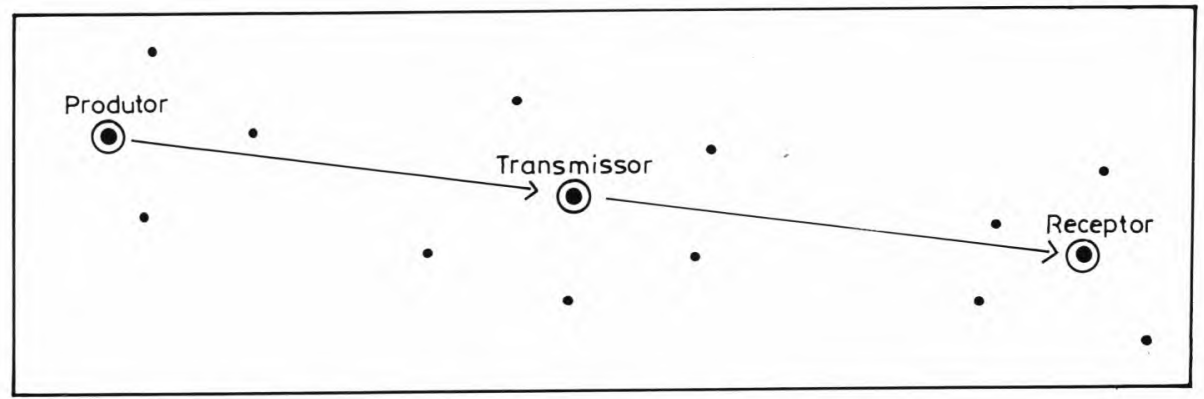

- Povoado maior Trajecto dos bens metálicos

- Povoado menor

FIG. 3 - Modelo de circulação do bronze.
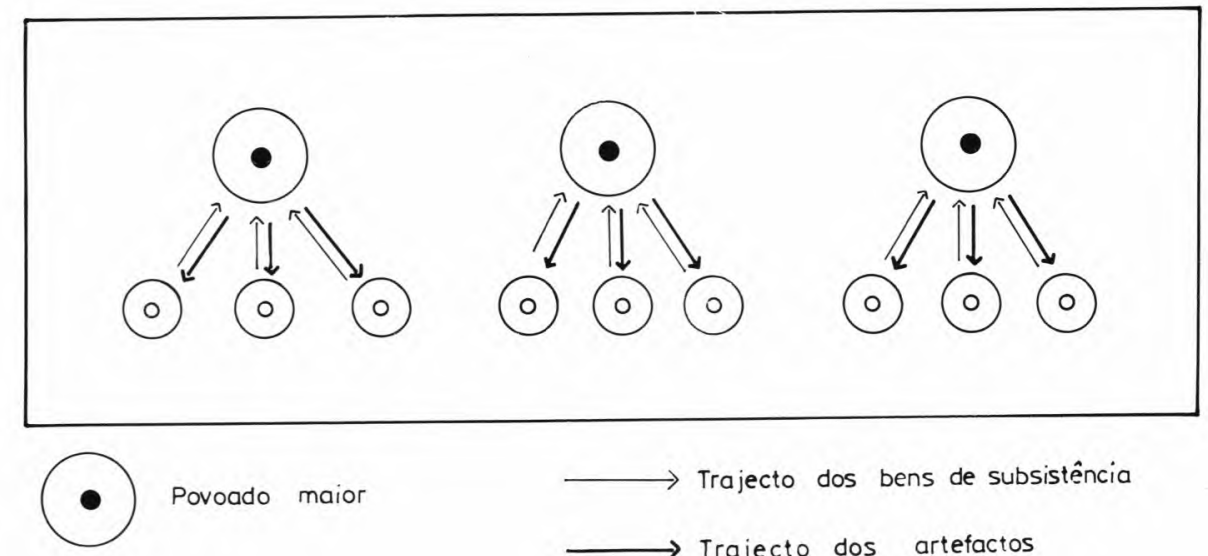

$\rightarrow$ Trajecto dos bens de subsistência

(0) Povoado menor

$\longrightarrow$ Trajecto dos artefactos

FIG. 4 - Modelo de circulação do bronze e outros bens. 


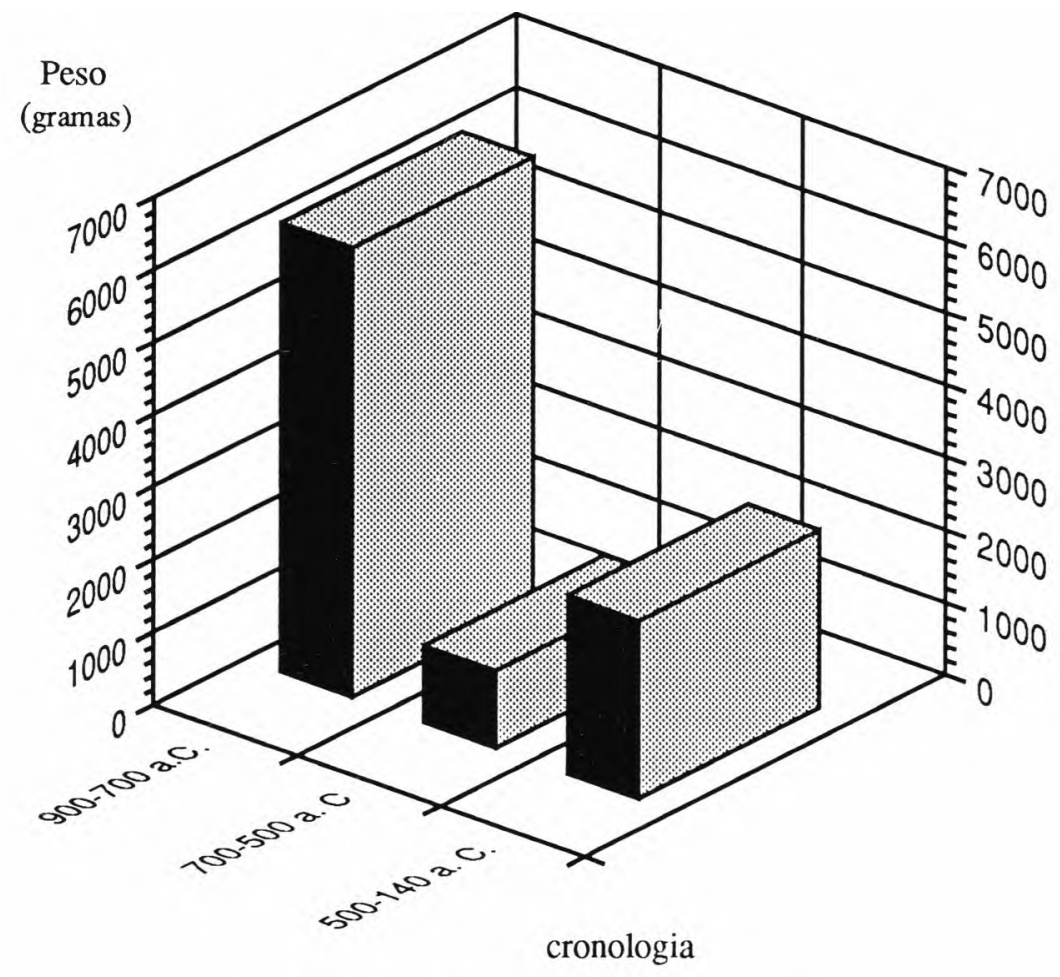

FIG. 5 - Peso das jóias de ouro na área castreja. 


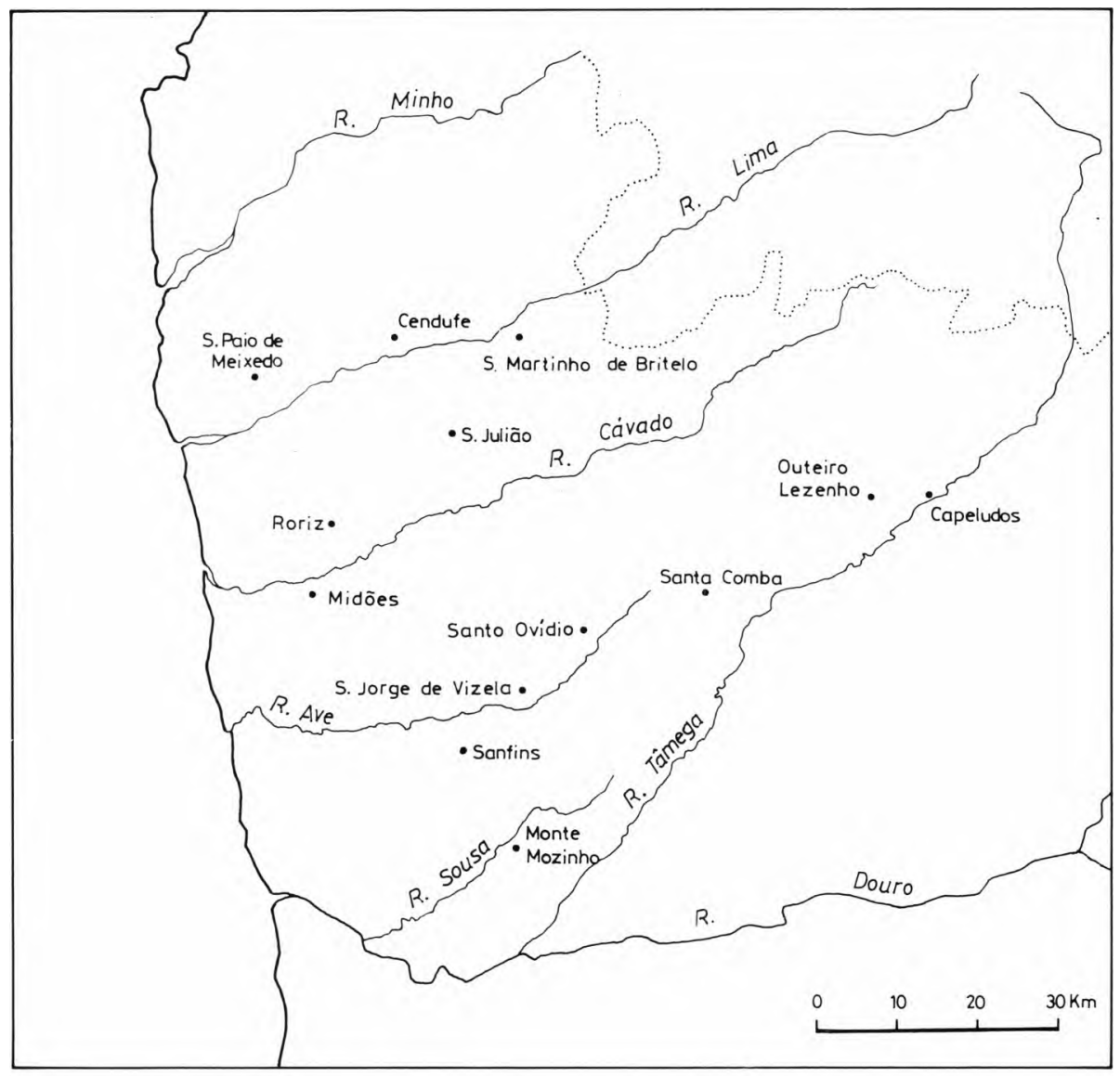

Fig. 6 - Localização das estátuas de guerreiros galaicos. 


\title{
COMENTÁRIO
}

\author{
A EVOLUÇÃO DA CULTURA CASTREJA
}

de RAQUEL VilaÇA

(Assistente da Faculdade de Letras de Coimbra)

A evolução da cultura castreja de Jorge de Alarcão merece-nos alguns comentários de pormenor e outros de ordem mais geral. Em relação aos primeiros, a nossa atenção incidirá no período compreendido entre os séculos X e VII a.C.

Numa perspectiva de fundo, gostaríamos de reflectir sobretudo na opção metodológica adoptada e nas suas implicações. O objectivo daquele texto é o de analisar e explicar, dum ponto de vista socioeconómico e sociopolítico, as permanências e as mudanças de uma dada região ao longo de um determinado período de tempo. Este compreende cerca de 1500 anos e aquela excede bastante, para sul, os limites geográficos tradicionalmente apontados para a área da "cultura castreja".

Esta abordagem de natureza macro-espacial e macro-temporal dános uma visão mais globalizante e contínua, remetendo para segundo plano as especificidades regionais e conjunturais. É certo que muitas das interrogações suscitadas pelo texto em discussão só poderão ter resposta quando colocadas a uma outra escala de análise. Mas as generalizações, se entendidas com a devida prudência, poderão delinear pistas de investigação da maior pertinência.

É neste carácter problematizante do tema em epígrafe que o texto se torna inovador.

Esta visão do processo histórico, baseada na continuidade estrutural entre os sistemas de diferentes épocas, tem sido, aliás, adoptada em diferentes regiões e por distintos investigadores. Nesta ordem de ideias, J. Alarcão distingue três fases fundamentais da evolução, as quais se

Conimbriga, 31 (1992), 73-83 
pautam pela tendência geral de comportamento das comunidades humanas, com alterações cíclicas de integração e de desintegração social, de crescimento e de contracção económica.

A nível europeu, alguns investigadores têm explicado estas alterações do comportamento social a partir de conflitos gerados entre áreas centrais e áreas periféricas e em função da integração política das diferentes esferas regionais de poder. Este modelo, defendido, por exemplo, por Rowlands e outros para a Europa central e, aliás, alvo de críticas (GOSDEN, 1985), não parece ser aplicável ao caso em análise, como nota J. Alarcão.

Uma das virtualidades da análise de períodos de "história longa" é mostrar a inoperância dos esquemas evolucionistas e neo-evolucionistas estabelecidos quase sempre a partir de observações de etnólogos, em função do "tempo curto" do presente. A segunda fase proposta para a "cultura castreja" exemplifica bem como a estrutura hierárquica da sociedade de inícios do I milénio a.C, com "chefados" (independentemente das suas características particulares na região em apreço), é reversível e conduz ao seu desaparecimento, para ressurgirem de novo (com outras características) só nos finais do século II a.C.

Uma das inovações introduzidas no texto de J. Alarcão reside nos limites geográficos propostos para a área da "cultura castreja". Contrariamente à argumentação tradicional, que dava ênfase à distribuição de determinados aspectos da cultura material, a nova proposta baseia-se em argumentos linguísticos, onomásticos, cultuais e étnicos.

O primeiro problema que se nos levanta decorre, exactamente, da diferença de critérios utilizados para a delimitação geográfica da "cultura castreja". Partindo do princípio de que todos eles são legítimos, verificamos não haver coincidência espacial se utilizarmos os elementos da cultura material, por um lado, e os linguísticos, onomásticos, etc., por outro. Se nos basearmos nos primeiros, teremos de alargar os limites geográficos para norte e oriente (Galiza e Astúrias); utilizando os critérios propostos por J. Alarcão estas duas áreas terão de ser excluídas.

A segunda interrogação que nos surge é a de sabermos até que ponto estes últimos argumentos serão aceitáveis para o período inicial da "cultura castreja", isto é, como poderemos definir uma entidade cultural discreta com elementos que lhe são anacrónicos, ou, pelo menos, cuja suposta sincronia não pode ser comprovada? Naquele período, a unidade da área proposta talvez advenha da sua riqueza em recursos estañíferos e auríferos. 
Como referimos, vamos centrar a nossa atenção na primeira fase proposta para a "cultura castreja". J. Alarcão procura entender a integração económica e sociopolítica desta fase em função de razões económicas. É, pois, fundamental definir a natureza da produção, das trocas e dos mecanismos de acesso ao poder e os meios da sua manutenção. Como se sabe, as perspectivas sobre estas questões têm balançado entre os que atribuem um papel de destaque ao controlo sobre a produção de bens de subsistência, com domínio da terra, da tecnologia produtiva e da armazenagem, e os que realçam o controlo sobre diferentes acessos a bens e a recursos estratégicos e às relações de circulação e de trocas de longa distância.

Vejamos quais os elementos de que dispomos.

A ocupação de múltiplos castros nos séculos X/IX a.C., fenómeno que J. Alarcão designa por "acastelamento", é hoje indiscutível. Elementos, parcialmente inéditos, das escavações que temos realizado na zona raiana da Beira Interior confirmam este dado geral. O que nos levanta mais dúvidas, por falta de dados ou por ainda insuficientemente demonstrado, é a existência de uma real continuidade de ocupação dos castros a nível da implantação topográfica das estruturas habitacionais, das suas características técnicas e da respectiva organização espacial. O reconhecimento de uma ocupação posterior ao Bronze Final não traduz, necessariamente, uma continuidade cultural. Diversos castros possuem, por exemplo, uma ocupação calcolítica ou do Bronze Inicial e isso não é motivo para se afirmar que as origens da "cultura castreja" remontam a essa altura.

De momento, para a área em análise, apenas parece ter sido reconhecida uma verdadeira continuidade ocupacional no Coto da Pena (Caminha) (SILVA, 1986, 36). A ideia geral é, por conseguinte, a da existência de uma descontinuidade ocupacional entre a 1.- fase e as seguintes. Esta tendência repete-se, aliás, nas próprias Beiras. As perspectivas de uma continuidade ocupacional em S. Romão (Seia) goraram-se e os casos da Sr.- da Guia (Baiões), de St.- Luzia (Viseu) do Monte de São Martinho (Castelo Branco), aparentemente todos eles com materiais de diferentes épocas, não foram ainda esclarecidos.

Com efeito, o problema da continuidade ocupacional dos povoados do Bronze Final é dos mais prementes para a compreensão do funcionamento das comunidades desta região. Está ainda por determinar por que motivo alguns povoados são abandonados no século VII a. C., enquanto outros sobrevivem, ainda que remodelados ao nível da implantação e da 
organização espacial. É evidente que a resposta a esta questão terá de ser encontrada a nível regional, com a determinação das especificidades daqueles que são definitivamente abandonados e das particularidades dos que se mantêm.

À medida que o milénio avança, a tendência crescente, particularmente no seu final, parece ser a de um aumento e concentração da população, com o simultâneo abandono do modelo de dispersão populacional em pequenos aglomerados que caracteriza, globalmente, o povoamento do Bronze Final. É possível que uma das respostas a este problema se encontre na conjuntura supra-regional dos primeiros séculos do I milénio a.C. É que se há coincidência entre o fenómeno do "acastelamento" e da produção e circulação intensas do metal, essa simultaneidade também se verifica ao nível do abandono de inúmeros povoados e do colapso do segundo fenómeno.

Os motivos que levaram ao "acastelamento" deverão ser diversos, quer globalmente, quer a nível regional. Inserem-se, contudo, num quadro geral europeu de competição social latente e de instabilidade, mas não de natureza estritamente guerreira. Com efeito, como nota J. Alarcão, a evidência da existência de conflitos armados é limitadíssima.

Ainda que se tenha baseado no caso concreto do curso médio do Cávado, J. Alarcão considera como improvável uma possível competição entre diferentes comunidades pela posse da terra. E, se não nos parece totalmente incorrecto tomar este caso particular como um todo, é porque não conhecemos qualquer povoado desta época suficientemente grande para provocar problemas agudos ao nível da subsistência dos seus habitantes.

Esta é uma outra tendência geral da época: os povoados são sempre surpreendentemente pequenos, mesmo aqueles que, pelos materiais fornecidos, terão constituído ou desempenhado um papel de destaque.

Também é verdade que o número de armas é insignificante. É-o ao nível particular dos povoados e é-o igualmente em termos gerais, o que lhes confere um valor mais simbólico do que prático. O simbolismo guerreiro, o qual pode ser reduzido à mera representação iconográfica (caso das "esteias" estremenhas), intimida só por si. O confronto real não era necessário para regularizar e legitimar o poder.

Por outro lado, é importante sublinhar que o "acastelamento" não se traduz sempre na edificação de muralhas. São bem raros os casos em que podemos falar de povoados muralhados nesta época. Referimo-nos, evidentemente, a muralhas minimamente eficientes, para já não falar 
numa arquitectura militar. Muralhas como as de S. Romão ou da Sr-, da Guia, constituídas por blocos graníticos sobrepostos, a seco, nos espaços livres entre afloramentos, dificilmente terão tido, pelas suas dimensões e tecnologia, um carácter defensivo/militar, ou sequer de prestígio. Só em períodos posteriores encontramos muralhas capazes em termos militares, como sinal de uma estruturada hierarquia de povoamento ou testemunhando um trabalho comunal organizado.

A ideia de que, nos inícios do I milénio a. C., as comunidades desta área se encontravam em diferentes estádios de desenvolvimento sociopolítico e se inseriam num quadro geral de competição merece a nossa concordância. E cremos igualmente que esta instabilidade latente deverá ter sido motivada pela intensificação da produção metálica, com o respectivo controlo das áreas mineiras, e circulação do bronze.

Se concordamos na valorização destes aspectos, não devemos, porém, esquecer o carácter dual dos materiais de bronze, nem a complexidade das trocas em sociedades pré-estatais. Os primeiros podem ter uma funcionalidade utilitária ou simplesmente simbólica e as segundas não podem ser reduzidas à esfera económica, mas entendidas como um "fenómeno social total" (MAUSS, 1988, 200-201), com implicações sócio-religiosas, políticas ou outras.

Se reconhecemos que um dos aspectos que melhor caracteriza o período em análise é o incremento e a multiplicação, a nível numérico e funcional, dos artefactos de bronze, devemos aceitar como provável que o poder ou o prestígio deixou de se medir pela posse do metal per se. $\mathrm{O}$ valor de alguns objectos baseia-se na sua simbologia e não no facto de serem em bronze.

$\mathrm{Na}$ verdade, são raros os povoados que não tenham fornecido elementos comprovativos da posse do metal e, frequentemente também, do fabrico local da metalurgia. Regra geral, estas provas correspondem a artefactos de uso comum, envolvendo uma tecnologia simples e pouco metal. Mas, nesta época, era igualmente praticada uma outra metalurgia, mais sofisticada, exigindo um maior volume de metal e reservada a objectos de prestígio e/ou a outros, como alguns machados, feitos em série e cujo valor económico é muito mais explícito. Ainda que não totalmente desconhecidos, os indícios do fabrico, ou a própria presença, deste segundo grupo nos povoados do Bronze Final são muito menos evidentes.

Esta dualidade do metal deverá traduzir, como sublinha Rowlands, a existência de dois níveis de trocas (ROWLANDS, 1987). Um seria mais 
denso, com base nos produtos locais, nos artefactos funcionais, e incluindo também bens de subsistência. $O$ outro seria à escala inter-regional, envolvendo bens de prestígio, os quais eram utilizados para estabelecer ou fortalecer alianças e acordos diplomáticos, trazendo prestígio e reforçando o status. Estas práticas sociopolíticas ajudariam a compreender a grande dispersão geográfica de determinados objectos (Kristiansen, 1981).

Como nota Bradley, é a relação entre as partes de uma transacção que determina o carácter dos itens que são trocados, isto é, os distintos caracteres dos objectos trocados são ditados pela distância sociopolítica dos participantes (BRADLEY, 1985, 702).

Tendo em conta este quadro geral de fundo, passemos à análise dos dois modelos de povoamento propostos. Ambos contemplam a existência de povoados maiores e outros menores. Divergem quanto à valorização da natureza dos bens — no primeiro modelo os bens metálicos são exclusivos, no segundo, além destes, também se têm em conta os bens de consumo; e afastam-se ainda no que respeita ao nível das trocas - no primeiro caso, as trocas são horizontais, equilibradas, entre iguais, no segundo, o nível de trocas e de produção é assimétrico e vertical.

$\mathrm{O}$ modelo da fig. 3 acusa um alto grau de especialização funcional dos povoados, valorizando-se a existência de agentes próprios, que distribuíam o que antes tinham adquirido. Neste modelo, os bens metálicos possuem um claro valor económico. E óbvia a necessidade de admitir a existência de outros povoados que ficariam à margem da produção e da circulação do metal. Discordamos, porém, quanto ao facto de serem necessariamente mais pequenos. Por exemplo, a Bouça do Frade (Baião), que se insere neste tipo, tem cerca de 2 ha (JORGE, 1988, 2), tanto quanto os maiores povoados conhecidos, com uso e produção local do bronze.

É igualmente possível classificar como receptores alguns povoados, como S. Julião (Vila Verde), que adquiriam objectos metálicos a outrem, uma vez que não os produziam localmente. Povoados produtores do bronze, no sentido de produzirem localmente artefactos para uso próprio, são muito mais frequentes e poderíamos apontar inúmeros exemplos. Mas já encontramos sérias dificuldades em distinguir um povoado produtor do metal com vista à sua exportação. Sucede o mesmo para a identificação de povoados transmissores.

Este modelo encontra, por conseguinte, objecções de natureza arqueológica, as quais, aliás, não são exclusivas à área em análise, mas 
comuns a toda a Europa atlântica. Conhecemos milhares de objectos metálicos, alguns resultantes de um fabrico em série e exigindo grandes quantidades de metal, mas nos povoados que têm sido escavados não há provas significativas da sua produção. Os meios técnicos de produção revelam, invariavelmente, uma produção artesanal e de pequena escala, para consumo local, ou, eventualmente, regional.

O primeiro modelo implica, ainda, a existência de uma divisão social do trabalho. Sem dúvida que alguns objectos de bronze e determinadas cerâmicas, com fabricos de grande especialização, com formas "standard" ou com a padronização de determinados motivos, sugerem uma certa "profissionalização". Como se sabe, Childe defendeu a exclusividade de artífices itinerantes a tempo inteiro. Os dados fornecidos pelos povoados dizem-nos que também haveria artesãos integrados socialmente na comunidade em que habitavam, trabalhando a tempo parcial, e conjugando a sua actividade de artífices com a produção de bens de primeira necessidade. Na verdade, a característica geral dos povoados que conhecemos vai no sentido de uma grande autonomia e autosuficiência em termos de produção de bens alimentares e outros, com indícios pouco consistentes de uma especialização a tempo inteiro ou de grandes acumulações de excedentes.

No segundo modelo proposto, há o claro reconhecimento de "chefes" coordenadores das trocas e de subordinados, os quais pagam tributos ou corveias de bens alimentares. O seu poder e riqueza parecem basear-se no controlo da produção de bens de consumo. Neste esquema não são contemplados os povoados sem metal, o que, arqueológicamente, é negado.

Este modelo envolve uma nítida hierarquia de povoamento, indispensável, como nos diz J. Alarcão, para o funcionamento controlado da sociedade. No entanto, é-nos difícil discernir, a partir do registo arqueológico, modalidades de povoamento testemunhadoras de uma hierarquização e estratificação dos povoados. Não nos parece que essa hierarquia possa ser observada apenas na oposição entre grandes povoados e pequenos povoados.

Se atendermos ao modelo proposto, os povoados maiores não deveriam proporcionar elementos significativos relacionados com a produção de bens de subsistência. Mas todos os povoados têm fornecido múltiplas provas de uma auto-suficiência na produção de bens de consumo.

Este modelo relaciona-se directamente com a problemática da existência de "chefes". O cerne da questão está na definição, para o tempo 
e área em análise, dos critérios identificadores de "chefes", pois, como nos lembra Earle, há uma grande variedade de chefados (EARLE, 1987). Por outro lado, o próprio modelo de chefado tem sido alterado ao longo do tempo, desde as primeiras propostas de Service e de Fried, até aos contributos de Peebles e Kus, Renfrew, Earle e outros.

$\mathrm{Na}$ área galaico-lusitana não nos parece ser possível identificá-los em função do tamanho dos povoados e correlativa densidade populacional. O povoado da Senhora da Guia (Baiões), tomado por J. Alarcão como testemunho da existência de um chefe, não chega a 2 ha $\left(\mathrm{c} .17100 \mathrm{~m}^{2}\right)$.

A arquitectura doméstica e defensiva não são igualmente reveladoras da existência de "chefes". Na primeira, não se conhecem edifícios maiores (eventuais casas de "chefes") e a segunda não revela grandes investimentos de energia e de trabalho humano.

A existência de significativas acumulações de excedentes também não tem correspondência consistente ao nível arqueológico. $O$ que encontramos é uma generalizada autonomia na subsistência. Note-se que este aspecto foi valorizado por Peebles e Kus, autores que propõem o abandono do critério da redistribuição (PEEBLES e Kus, 1977, 421).

Por outro lado, também já vimos que a mera posse e produção do bronze, porque generalizadas, não traziam, só por si, riqueza e poder.

$\mathrm{Na}$ ausência de informação a nível das práticas mortuárias, estamos circunscritos a determinadas entidades arqueológicas, cuja especificidade e exclusividade, a nível da matéria-prima, qualidade de fabrico ou utilização excepcional, poderão ser indicadoras de "chefes". J. Alarcão refere os principais: "esteias", joias de ouro, artefactos de ferro e elementos rituais (espetos, taças, furcula, etc.); poderíamos juntar ainda as contas de colar de âmbar e de pasta vítrea.

Com base nestes elementos, é-nos proposta a existência de quatro redes de "chefados": três relacionadas com joias de ouro ( Beira Alta, vale do Ave e vale do Tâmega) e a quarta com as "esteias" (Beira Transmontana e Beira Baixa).

Note-se que, na vasta área galaico-lusitana, a sub-região onde as joias de ouro são raras ou inexistentes corresponde à região de maior riqueza aurífera. Sublinhe-se igualmente que a zona transmontana a norte do Douro não forneceu, até hoje, elementos pertinentes para esta problemática.

A respeito das "estelas", J. Alarcão sugere-nos que a sua seriação poderia basear-se numa diversificação em função do status, isto é, quanto maior fosse o número de objectos representado, mais elevado seria o 
status do "chefe". A ser verdadeira esta sugestão, teríamos aqui uma prova inequívoca de um "complex chiefdom", com chefes principais e outros dependentes (YOFFEE, 1993,62). As diferenças a nível de tipologia e de peso das joias de ouro indicaria o mesmo. A valorização que J. Alarcão propõe para o significado das "esteias" aproxima-se da proposta de Barcelo. Segundo este investigador, a falta de regularidade no padrão iconográfico deve ser explicada como o resultado de uma variabilidade social e pela falta de uma fórmula estável de identidade para as elites sociais, isto é, a sua variabilidade formal é o resultado da falta de coesão social entre elas (BARCELO, 1992).

Não vamos discutir aqui o inequívoco interesse destas sugestões. Gostaríamos apenas de lembrar uma outra proposta que, aliás, não contradiz aquelas, mas que se centra nos locais de achado das "esteias". Ruíz-Gálvez Priego e Galan Domingo consideram que as "esteias" seriam marcos colocados em locais de passagem, visíveis à distância, e a sua posição vertical denunciava isso mesmo e não a marcação de algo, nomeadamente de sepulturas (RUIZ-GALVEZ PRIEGO e GALAN DOMINGO, 1991).

Como testemunhos de poder, a sua colocação em locais de passagem e de circuitos estratégicos, apela para a importância que, a nível regional, teria tido a competição pelo acesso e controlo de recursos estratégicos, não só locais, mas também daqueles que estavam posicionados nas vias percorridas na altura.

O achado das "esteias" fora dos povoados (as de S. Martinho são excepção e levantam problemas), contrariamente ao das joias de ouro, poderá assinalar uma outra particularidade da Beira Interior no quadro da área galaico-lusitana: naquela região, o poder também se manifestava fora dos espaços habitacionais, expondo-se em áreas abertas, percorridas por outros, estranhos às comunidades locais, criando espaços verdadeiramente sociais.

Independentemente das particularidades regionais, o que é certo é que, na área proposta, os níveis discretos da hierarquia sociopolítica identificam-se através de determinados itens de prestígio e de símbolos de status.

Porém, como notam alguns autores, o poder e o status social não se medem no acesso aos itens de prestígio, isto é, as alianças políticas e diplomáticas responsáveis por essas ofertas não trazem prestígio per se. Elas apenas fornecem a base de suporte aos "chefes" locais para competirem entre si através da capacidade de organizarem e protagonizarem 
cerimónias onde pudessem ostentar publicamente esses elementos que legitimavam o poder (BRADLEY, 1981, 235). Mas sabemos também que essas cerimónias - verdadeiras instituições da altura - poderiam assumir a forma de banquetes rituais, onde o consumo de carne teria um lugar de destaque. Neste sentido, não podemos esquecer o papel de alguns "chefados" sobre a produção agropastoril.

O êxito dos "chefados" do Bronze Final, quer na zona galaico-lusitana, quer em muitas outras regiões europeias, poderá ter-se baseado nesta comunhão de elementos rituais e simbólicos, os quais constituíram um verdadeiro "estilo internacional" (EARLE, 1989).

Uma vez perdidas as referências desses elementos simbólicos instrumentos, por excelência, da integração social (BOURDIEU, 1989,10) - a área galaico-lusitana desintegrou-se política e socialmente, à semelhança de tantas outras.

Coimbra, Maio de 1993.

\section{BIBLIOGRAFIA}

Barcelo, J. A. (1992), Una interpretación socioeconomica del Bronce Final en el Sudoeste de la Península Iberica, "Trabajos de Prehistoria", 49, 259-275.

Bourdieu, P. (1989), O poder simbólico, Difel, Memoria e Sociedade.

BRADLEY, R. (1981), Economie growth and social change: two examples from prehistoric Europe, in SHERIDAN, A. e BAILEY, G. (eds.), Economic Archaeology, BAR, i.s., 96, 231-237.

BRADLEY, R. (1985), Exchange and social distance - the structure of bronze artefact distributions, "Man", n.s., 20 (1), 692-704.

EARLE, T. K. (1987), Chiefdoms in archaeological and ethnohistoricalperspective, "Annual Reviews in Anthropology", 16, 279-308

id. (1989), The Evolution of Chief doms, "Current Anthropology", 30 (1), $84-88$

Fried, M. H. (1967), The Evolution of Political Society, New York, Studies in Anthropology.

Gosden, C. (1985), Gifts and Kin in Early Iron Age Europe, "Man”, n.s., 20 (3), 475-493.

JORGE, S. 0. (1988), O povoado da Bouça do Frade (Baião) no quadro do Bronze Final do Norte de Portugal, Porto, GEAP, Monografias Arqueológicas, 2.

Kristiansen, K. (1991), Chief doms, states, and systems of social evolution, in EarLe, T. (ed.), Power, economy and ideology, Cambridge University Press,16-43.

Martins, M. (1990), O povoamento proto-histórico e a romanização da bacia do curso médio do Cávado, Braga, Cadernos de Arqueologia-Monografias, 5.

Conimbriga, 31 (1992), 73-83 
MAuss, M. (1988), Ensaio sobre a dádiva, Lisboa, Edições 70/Perspectivas do Homem.

PEEBLES, C. S. e Kus, S. M. (1977), Some archaeological correlates of ranked societies, "American Antiquity", 42(3), 421-448.

RENFREW, C. (1982), Socio-economic change in ranked societies, in RENFREW, C. e SHEnnan, S. (eds.), Ranking, resource and exchange, Cambridge, Cambridge University Press, New Directions in Archaeology, 1-8

id. (1984),Approaches to Social Archaeology, Oxford, Edinburgh University Press.

RowlandS, M. (1987), Centre and periphery: a review of a concept, in RowlANDS, M., LARSEN, M. e KRISTIANSEN, K. (eds), Centre and periphery in the ancient world, Cambridge University Press, New Directions in Archaeology, 1-11.

Rowlands, M. (1980),Kinship, alliance and exchange in the European Bronze Age, in BARRet, J. e Bradley, R. (eds.), The British Later Bronze Age, BAR, b.s., 83, part 1, 15-55.

Ruíz-Gálvez Priego, M. e Galan Domingo, E.(1991), Las Estelas del Suroeste como hitos de vías ganaderas y rutas comerciales, "Trabaios de Prehistoria", $48,257-273$.

Silva, A. C. F. (1986), A Cultura Castreja no Noroeste de Portugal, Museu Arqueológico da Citânia de Sanfins, Paços de Ferreira.

YoffeE, N. (1993), Too many chiefs? (or, Safe texts for the'90s), in YoFEe, N. e SHERRATT, A. (eds.),Archaelogical theory: who sets the agenda? New Directions in Archeology, Cambridge University Press, p. 60-78

Conimbriga, 31 (1992), 73-83 